\title{
FORMAS DE RELIGIOSIDAD DE LA NOBLEZA NAVARRA EN LA EDAD MODERNA
}

\author{
POR \\ PABlo Orduna Portús \\ Doctor en Historia moderna \\ Profesor Adjunto de la Universidad Internacional de la Rioja

\section{RESUMEN} \\ Durante el Antiguo Régimen, la religión impregnaba todos los actos de ma- \\ yor trascendencia social, comunitaria y cultural. A este respecto, nada era impro- \\ visado por la nobleza navarra. Se ponía un especial cuidado en los detalles de \\ cada ritual funerario y en las disposiciones de última voluntad. Se tenía presente \\ la necesidad de buscar ayuda en la tierra para la expiación en el Purgatorio de \\ aquellos pecados cometidos a lo largo de su vida terrenal. En ese sentido jugaron \\ un papel sumamente importante la fundación de capellanías y las mandas pías \\ dispuestas en los testamentos.
}

PALABRAS ClAVE: Navarra, nobleza, elites, ritual funerario, obras pías, capellanías.

\section{RELIGIOUS PRACTICES OF THE NAVARRESSE NOBILITY IN THE MODERN AGE}

\begin{abstract}
During the Old Regime, religion permeated all important social, community and cultural events. In this regard, nothing was improvised by the navarresse nobility. A special care was put into the details of each funeral ritual and of the last will. Traditionally seeking help on Earth to atone in Purgatory their sins committed during his earthly life. In that sense, the chaplaincies pious works, arranged in wills play a significant role.
\end{abstract}

KEY WORDS: Navarre, nobility, elite, funeral ritual, pious works, chaplaincies.

Recibido/Received: 29-03-2010

Aceptado/Accepted: 07-11-2011 


\section{LA HORA DE LA MUERTE: ADVOCACIONES TESTAMENTARIAS}

Tras el Concilio de Trento la mentalidad de la Europa católica sobre la vida y la muerte cambió en gran medida. ${ }^{1}$ Había surgido en el seno de la Iglesia un deseo de mover conciencias con el fin de que la vida fuera considerada como una preparación para el bien morir. ${ }^{2}$ No era posible ya satisfacer al cuerpo y al alma al unísono, pues el fortalecimiento de uno era la debilidad del otro. Es decir, la muerte de uno suponía la plenitud del contrario por lo que el ánima humana, requerida por la carne y el espíritu, debía optar en vida como el viajero entre dos caminos. ${ }^{3}$ La doctrina católica había reafirmado tras el concilio tridentino que el reposo eterno sólo era privilegio exclusivo de los justos, mientras que los impíos sufrirían del tormento por toda la eternidad. Era un aviso dirigido a los vivos, una invitación a la meditación sobre el destino mortal del hombre. ${ }^{4}$

Durante la Modernidad, la realización de una buena recapitulación vital mediante un correcto examen y descargo de conciencia, se convirtió en uno de los hechos transcendentales de todo hombre inmerso en el ambiente mental existente en la sociedad del Antiguo Régimen. Los testamentos, abiertos o cerrados, constituyeron de esta manera el núcleo fundamental de las escrituras de últimas voluntades..$^{5}$

Según Alexo Venegas, el testamento permitía a todo cristiano dar a cada uno lo suyo, es decir, «la hacienda a los herederos, el cuerpo a la tierra y el alma a Dios que la crió de la nada». ${ }^{6}$ Para el palaciano de Olloqui, en 1561 aún era más este documento. Según decía, dictaba su testamento «por hacer lo que todo ca-

\footnotetext{
${ }^{1}$ Casey, J. 2002. «Queriendo poner mi ánima en carrera de salvación: la muerte en Granada (siglos XVII y XVIII)» en G. Franco Rubio (coord.), De mentalidades y formas culturales en la Edad Moderna. Cuadernos de Historia Moderna, Anejo I 17-43: 17-43 y Martínez, F. 2002. «Del modelo medieval a la Contrarreforma: la clericalización de la muerte», en J. Aurell y J. Pavón (eds.), Ante la muerte. Actitudes, espacios y formas en la España Medieval: 215-255. Pamplona: EUNSA.

${ }^{2}$ Male, E. 1986. L'art religieux du XIII' siécle en France : 206-217 Paris: Colin.

${ }^{3}$ Erasmo, D. 1998. El Enquiridion o manual del caballero cristiano: regla I, cap. VII, Valladolid: Secretariado de Publicaciones de la Universidad de Valladolid.

${ }^{4}$ Bouza, J. L. 1990. Religiosidad contrarreformista y cultura simbólica del Barroco: 377-398 Madrid: CSIC. Quizá por ello, muchos caballeros navarros se decidieron por realizar sus testamentos ante su próxima partida al socorro de Malta en 1565 contra el otomano u otros destinos militares. Y así lo harían el señor de Eriete, don Juan Piñeiro, don Antonio de Falces y Aibar antes de dirigirse en 1636 a la lucha contra Francia o don Miguel de Ezpeleta en 1668 que tenía ordenado marchar a Flandes. Ver respectivamente: Archivo General de Navarra [AGN], TT.RR., Procesos judiciales, 1636, fol. 6; AGN, TT.RR., Procesos judiciales, 59069, fol. 6 y Archivo de Protocolos Notariales de Pamplona [APNP], notario Francisco Orta, Pamplona, leg. 248, doc. 359.

${ }^{5}$ Solchaga, J. 1959. El testamento ante párroco en Navarra. Zaragoza: Tipográfica La Académica.

${ }^{6}$ Venegas, A. 1583. Agonía del tránsito de la muerte: XXr Valladolid.
} 
tólico cristiano debe de disponer y ordenar de sus bienes antes de su muerte».7 Así lo corroboraba también en 1584 don Luis de Donamaría, señor del palacio de Ezperun. Manifestaba que, «visto por mí el peligro en que cada cristiano está de poder morir de muerte repentina y súbita, como pasar esto por muchos se ve ocularmente cada día y, tras esto, suceder muchos pleitos y enojos entre los sucesores». 8

Doña María Ruiz de Bergara, viuda de don Antonio de Góngora «ya difunto, señor que fue del lugar de Góngora y San Adrián y de los palacios y patronazgos de los lugares de Ziordia y Laguardia y de los palacios de la villa de Dicastillo», otorgaba testamento en 1605 en Pamplona estando enferma «pero en muy buen juicio». La dama veía acercarse la muerte y ante Jesucristo afirmaba entender «que es cosa natural a toda persona viviente en este mundo». Por ello se había decidido a testar con objeto de que «después de mis días no haya pleitos ni cuestiones entre mis hijos ni otras personas». Así, tras revocar los testamentos anteriores comenzaba el nuevo documento encomendando primero su alma a Jesucristo y a la Virgen María. ${ }^{9}$

El testamento era un buen medio para limpiar la conciencia y evitar pleitos a aquéllos que sucedieran al finado, y para invertir a la vez ciertos bienes en la salvación de la propia alma.

Tras las disposiciones de estos documentos, aparecía impresa la estratificación social y las diferencias personales y de grupo propias del Antiguo Régimen. No obstante, todos ellos comenzaban con unas cláusulas «religioso-confesionales» con ciertas formas estandarizadas por testadores y escribanos, cuyo fin era validar su significación espiritual. Este repertorio otorgaba a estas actas un carácter plenamente religioso, «reflejo de la mentalidad sacralizada imperante, pero también 'pública y notoria' existente». ${ }^{10} \mathrm{La}$ expresión de la fe, presente en la sociedad europea de la Era Confesional se encontraba en las primeras cláusulas testamentarias.

La inclusión de la profesión de fe otorgaba una especie de «legalidad moral» al documento. ${ }^{11}$ En algunos casos el testador incluía inmediatamente su deseo e intención de mantenerse fiel hasta su muerte a sus creencias en previsión de no estar en aquellos momentos mentalmente sano.

${ }^{7}$ Archivo Diocesano de Pamplona [ADP], C/148-n ${ }^{\circ} 2$, fol. 26.

${ }^{8}$ APNP, notario Miguel Arizcun, Pamplona, leg. 6, I, 19 de junio de 1584.

9 APNP, notario Miguel de Burutain, Pamplona, caja 18885/1, leg. 21-III, doc 3, 26 de noviembre de 1605.

${ }^{10}$ García Fernández, M. 1996. Los castellanos y la muerte. Religiosidad y comportamientos colectivos en el Antiguo Régimen: 22-24 Valladolid: Junta de Castilla Y León.

${ }^{11}$ Lorenzo, Fco. J. 1991. Muerte y ritual en la Edad Moderna. El caso de Zamora (1500-1800): 19, 33 y 80 Salamanca: Universidad de Salamanca. 
Erasmo, como otros tratadistas de la muerte en aquel tiempo, avisaba que, durante la agonía, el moribundo podía ser tentado y atacado diabólicamente: «En este artículo de la muerte, Satanás trae a la memoria del hombre todo cuanto puede matar la lumbre de la fe y de la esperanza que tiene. [...] Le tienta de fe, para que dude en la Santa Escritura, y en los artículos de la Iglesia».12 Por eso en estas manifestaciones los testadores solían expresar su fe en los dogmas de la Iglesia.

En 1541 los palacianos de Aibar encomendaban su alma a Dios, la Virgen y todos los santos con objeto de que «en el horrible y terrible y oscuro día de nuestros finamientos e fin de nuestros días les plega e quieran asistir y resistir al espíritu maligno y a las fuerzas ilusiones e tentaciones que suelen e quieren tentar a los cristianos o nos podrían impremir el paso de la muerte contra nuestra fe católica, en la cual desde ahora protestamos nosotros los dichos testadores y cada uno de nos de vivir y morir $t_{\gg} .{ }^{13}$ Martín de Gaztelu, palaciano consorte de Eza, apuntaba que, como buen cristiano, al morir lo hacía «detestando, abominando e reprobando todas las herejías, apostasías y errores que la Santa Católica y Apostólica Iglesia Romana detesta, abomina y reprueba»..$^{14}$

Es cierto que la profesión de fe no siempre se hallaba en la redacción de las últimas voluntades de los palacianos navarros, pero nadie olvidaba encomendar su alma a Dios o a la Virgen y a los santos intercesores. En estas cláusulas declaratorias se distingue la exaltación de la fe y la solicitud de intercesores, lo cual nos introduce en el ámbito de las devociones personales. La mayoría de ellas comenzaban con las fórmulas «In domine amen» $\mathrm{O}$ «In dei nomine», en latín o castellano.

En 1612 don Fernando Baquedano, vecino de Zábal, encabezaba su testamento empleando la fórmula «In domine amen» asegurando «estando enfermo en cama de grande enfermedad aunque en mi buen juicio natural y palabra manifiesta que al nuestro señor fue servido deme los dar, teniendo de la muerte y deseando poner mi ánima en carrera de salvación, creyendo como firmemente creo en la santa fe católica y en todo aquello que bueno y fiel cristiano debe tener y creer». 15

En 1643 la vizcondesa de Castejón encomendaba su alma a Dios «que la crió y redimió, y le suplico por su infinita misericordia, que, luego que haga separación de mi cuerpo, sea servido de colocarla con los demás bienaventurados

\footnotetext{
12 Erasmo, D. 2000. Preparación y aparejo para bien morir: 281 Madrid: Fundación Universitaria Española.

${ }^{13}$ AGN, TT. RR., Procesos judiciales, 68504, fol. 11v.

${ }^{14}$ AGN, TT. RR., Procesos judiciales, 98909 , s/n fol.

15 APNP, notario Pedro Salinas, Salinas de Oro, caja 949/2, leg. 72 doc. 4, año 1612.
} 
en su santo Reino; y a la Virgen santísima, madre suya, y a los demás santos y santas, sean mis intercesores y abogados con su divina Majestad, para que se sirva de usar conmigo su misericordia». ${ }^{16}$

Difícilmente se puede encontrar un testamento redactado entre los siglos XVI y XVII que no comience con una invocación a Dios seguida de alguna alusión doctrinal referente a la transitoriedad de la existencia terrenal. Esto reflejaba el providencialismo divino y el intenso carácter tanático que impregnaba la mentalidad religiosa de la sociedad en la Edad Moderna. ${ }^{17}$ En ocasiones se suplica la ayuda divina para lograr disponer todo de la mejor manera. Así la señora de Góngora en 1656 solicitaba ayuda a Dios «con celo de acertar en materia de que pende la eternidad de dicha o desventura [...] y conociendo que el yerro en punto de tanta importancia solo sucede una vez en lugar de enmienda». ${ }^{18}$

A pesar de haberse cuestionado el papel mediador de los santos o de la Virgen por movimientos reformadores de la primera mitad del siglo XVI, éste fue reafirmado por el Concilio de Trento y se mantenía vivo en la religiosidad popular. García Bourrellier, cita las advocaciones testamentarias de los marqueses de Falces. ${ }^{19}$ Diego de Croy invocaba a la Trinidad y a la Virgen María. Su hijo Felicio añade a «Dios nuestro Señor». Don Miguel de Ursúa, palaciano de Arizcun, no dudó en encomendarse a San Miguel Arcángel. ${ }^{20}$ En 1606 don Martín de Gaztelu y su esposa doña Catalina de Andueza, palacianos de Gaztelu en Echalar, además de al ángel custodio solicitaron por sus almas en el juicio final la intercesión de los grandes santos de la cristiandad: San Pedro y San Pablo. ${ }^{21}$

En 1680 el maestre de campo don Francisco de Sarabia, caballero del hábito de Santiago y dueño del palacio del lugar de Erasun, y vecino de Pamplona, se hallaba postrado en la cama pero por «su buen juicio y sana memoria» decide testar viendo que su muerte está cercana. Para realizarlo de forma correcta hizo llamar al escribano público Juan Arlegui y a sus testigos y se dispuso a establecer sus últimas voluntades teniendo en cuenta que «la dicha enfermedad es muy grave y no le da lugar para disponer y ordenar su testamento con la deliberación, extensión, consideración y sosiego que se requiere ni tampoco puede con esta prontitud decidir algunas dudas que se le ofrecen porque no está enterado del contenimiento de unos instrumentos que, con vista de ellos, es pre-

\footnotetext{
${ }^{16}$ Archivo General de Simancas [AGS], Contaduría de Mercedes, leg. 1.181, n. 10.

17 Peñafiel, A. 1987. Testamento y buena muerte. Un estudio de mentalidades en la Murcia del siglo XVIII: 38-41 Murcia: Academia Alfonso X El Sabio.

18 AGN-Archivo Marqués de Góngora [AMG], fajo $3^{\circ}$, doc. 21.

${ }_{19}$ García Bourrellier, C. R. 1998. Nobleza titulada y organización señorial en Navarra (siglo XVII): 549 y ss. Pamplona: Tesis doctoral inédita.

${ }^{20}$ Aguirre, $\mathrm{M}^{\mathrm{a}}$. C. 1978. Los agotes: 327-328 Pamplona: Príncipe de Viana.

${ }^{21} \mathrm{ADP}, \mathrm{C} / 273-\mathrm{n}^{\circ} 16$, fol. 13.
} 
ciso tomar disposición en la distribución manda o sucesión de algunos bienes que como queda dicho está en duda sean libres o haya llamamiento o gravamen en ellos como se referirá más adelante, por tanto, en la mejor y más segura vía, modo forma y manera que de dueño puede y debe ha lugar». Tras revocar todo codicilo anterior, encomendaba su alma a Dios y rogaba a la Virgen del Camino, «su ángel de la guarda y a todos los demás santos y santas de su devoción» para que intercedieran por él en el Juicio Final. ${ }^{22}$

Ejemplos parecidos se dieron de nobles navarros que solicitaban en sus advocaciones la ayuda de otros ángeles y santos como San Gabriel Arcángel, San Juan Bautista, San José, San Francisco, Santa Ana, San Antonio Abad, San Antonio de Padua, San Diego de Alcalá y por supuesto San Francisco Javier.

\section{LA HORA DE LA MUERTE: HONRAS FÚNEBRES}

Durante la reforma del mundo cristiano en la Temprana Edad Moderna el concepto generalizado del 'ritual' vino a ser entendido como una clase de actividad diferenciada (Muir, 1997: 7). En lo relativo a las honras fúnebres el Concilio de Trento no inventó la visión moderna de la muerte, pero ayudó a su transformación. Mediante sus dogmas y disciplinas renovadas la 'domó', en palabras de García Fernández, consolidando todos los rituales que acompañaban a los duelos. ${ }^{23}$

Los moralistas exigían el olvido de la memoria humana del difunto reconociendo como única obra sólida y otorgante de la securitas cristiana a la virtud, los rituales mortuorios seguían, sin embargo, desarrollándose según la tradición. Sin embargo, el cambio estaba ya en marcha y la moderación en las honras dispensadas se convertía en una reafirmación del carácter perecedero del cuerpo y de la inmortalidad del alma. ${ }^{24}$

El nuevo puritanismo radical consideraba las honras dispensadas al cadáver por la piedad doméstica como algo contrario a la creencia de la inmortalidad del alma. Para la nueva escatología el cuerpo difunto no guardaba ya la unidad consustancial con la entidad espiritual que sobrevive..$^{25}$

Las medidas legales derivadas de lo dispuesto en Trento no se hicieron esperar. En Navarra la Novíssima Recopilación ${ }^{26}$ recogía las ordenanzas acerca de

\footnotetext{
22 APNP, notario Juan Arlegui, Pamplona, caja 19385/2, leg. 259, doc. 87, 13 de junio de 1680.

${ }^{23}$ García Fernández, M. 1996: 14.

${ }^{24}$ Rodríguez-San Pedro Bezares, L. E. y Sánchez Lora, J. L. 2000. Los siglos XVI y XVII. Cultura y vida cotidiana: 161-162 Madrid: Síntesis.

${ }^{25}$ Bouza, J. L. 1990: 383.

${ }^{26}$ Novíssima Recopilación de las Leyes del Reino de Navarra... Año 1735, Pamplona, 1964 [NR], $3,16,2-5$ y 8 .
} 
los funerales y lutos. En las Cortes de Tudela de 1558 una provisión temporal dispuso que dado que «en los mortuorios y defunciones de los que mueren en este Reino se tienen muchos excesos a cerca de los lutos que se dan. Y porque sería bien que en ello hubiese moderación, piden y suplican a vuestra Real Majestad sea servido de mandar proveer: que los dichos lutos no se puedan dar sino a marido, e mujer, e hijos, yerno, nuera, nietos, hermanos y herederos de los difuntos, y a los criados de la casa y servicio del difunto, y no a otras personas». ${ }^{27}$

Esta disposición la confirmaron las Cortes de Tudela de 1565 especificándose que «se entienda no solamente en mortuorios, sino también en novenas, cabo de año y aniversarios de difuntos; y que no se den lutos de paño [...] porque en esto suele haber mucho exceso y gasto superfluo». ${ }^{28}$ Posteriormente, las pragmáticas de Felipe II (1572) serían más restrictivas y sobre todo las de las Cortes de Tudela de 1695, que reglamentarían incluso todo lo relativo al vestir en las exequias fúnebres. ${ }^{29}$

En la mentalidad popular seguía vigente la creencia de la unidad, armonía y solidaridad entre vivos y muertos. ${ }^{30} \mathrm{Se}$ manifestaba en el puntual cumplimiento de los ritos prescritos por la tradición para con el cadáver y el honor familiar. Esta piedad, más cercana al hombre de la calle, consideraba tales honras fúnebres necesarias para que el muerto pudiepudiera participar en la resurrección de la carne. ${ }^{31}$

${ }^{27}$ Cortes de Tudela, 1558, provisión 10, temporal.

${ }^{28}$ Cortes de Tudela, 1565, ley 66.

${ }^{29}$ Cortes de Pamplona, 1572, tras la ley 37, fol. 14 y Cortes de Tudela, 1695, ley 20. Sin embargo, en 1612 existiría una excepción a estas restricciones del boato en el luto. Tal cambio se debió a la celebración de las exequias reales por la muerte de la esposa de Felipe III, ya que «en lo de las honras y lutos que son ocasión de la muerte de la reina nuestra señora, que está en el Cielo, desean hacer los pueblos y villas señaladamente llamadas a estas Cortes, pese a estar los pueblos tan empeñados y cargados de deudas; porque habiendo sido servido la persona real de vuestra majestad de escribir cartas a los dichos pueblos, haciéndoles la dicha muerte, y mandado que se hagan las dichas honras con las demostraciones de lutos acostumbradas, no pueden así los que han recibido las dichas cartas, como los que no las han recibido, deja de hacer las dichas honras [...], y haciéndolas es fuerza que las acompañen con lutos en las personas de los que gobernaban los dichos lugares al tiempo que sucedió la dicha muerte [...]. Y no parece que es de consideración para evitar este gasto el decir que los pueblos están empeñados, porque para ocasión tan del servicio a Vuestra Majestad, no parece que sería bastante excusa la susodicha». Cortes de Pamplona, 1612, ley 10, Acerca de los lutos, y gastos de las honras de la reina nuestra señora, acudiendo los lugares que asisten en Cortes al Virrey, les hará la merced, y gracia que hubiere lugar.

${ }^{30}$ Así por ejemplo, en 1631 Catalina de Abínzano exigía el desentierro de Catalina de Espinal, tres días sólo después de haber sido sepultada. Ésta había sido enterrada en una fuesa de la iglesia de San Pedro en Artajona donde yacía el cadáver del primer marido de la demandante, tenido por hombre principal del lugar. Al ser sepultada la fallecida, perteneciente al Tercer Estado, se habían sacado los huesos del dicho caballero, lo que exasperaba a su viuda que llegó a afirmar que tal era su pesar que casi había abortado por la presión de la criatura que esperaba de su segundo marido. Videgain, F. 1992. La muerte en Navarra a través de los siglos: 226-230 Torres de Elorz: Castuera.

31 Ariès, P. 1983. El hombre ante la muerte: 35 Madrid: Taurus. 
Superado el giro humanista del siglo XVI, la sociedad de la Edad Moderna abandonó el baile de las Danzas Macabras medievales por los Ars Moriendi como manuales de aproximación a lo sobrenatural de la muerte..$^{32}$

Múltiples tratados de 'buena muerte', como la Agonía del tránsito de la muerte, de Venegas (1583), las obras de Erasmo, Lutero o los ejercicios jesuíticos, plasmaron la mentalidad del periodo. Todo este proceso alcanzó su cenit durante la culminación barroca de la muerte cargada de una majestuosa escenografía pública entre catafalcos, iconografías y pompas fúnebres que dejaron en un segundo plano todo sentimiento privado.

A pesar de que los duelos continuaron celebrándose, desde principios del siglo XVIII no volvieron a alcanzar la pompa que habían tenido en las celebraciones funerarias precedentes. Sermones y oraciones fúnebres languidecieron al igual que las procesiones internas..$^{33}$

Sí es verdad que durante los siglos XVI y XVII algunos de los palacianos navarros optaron por señalar que sus honras fúnebres no excedieran en gastos de pompa. Fue por una pretendida humildad o por situaciones económicas adversas como la que atravesaba en 1687 don Juan de Ibero, señor de los palacios de Oteiza y Eraso. La crisis de sus rentas le obligó a ordenar que sus exequias se celebraran «sin que sobresalga en los gastos más de lo decente respecto de los tiempos apretados y los pocos medios con que hoy me hallo». ${ }^{34}$

La palaciana de los lugares de Esparza y Zariquiegui exigió en su testamento de 1690 como muestra de humildad que en su entierro «no se toquen las campanas a bando ni se lleve música. Y que mi cuerpo se lleve con la Cruz desde la casa donde muriere, y que no se ponga en la iglesia sobre bufete sino en el suelo. Y que el ataúd no se forre en felpa ni otro género de seda sino con bayeta negra». 35

Se siguieron publicando tratados cercanos a los artes moriendi en el Reino de Navarra a lo largo del Setecientos invitando a la reflexión y el examen de conciencia de todo buen cristiano ante la certeza de la muerte. Citamos los libros publicados en Pamplona de Josef Fierad (1789), La vida y muerte del hombre justo, propuesta en los ejemplos de San Josef, y de Jean Croiset (1732), Retiro espiritual para un día de cada mes: muy útil para la reforma de las costumbres, y para disponerse con una santa vida para una buena muerte.

${ }^{32}$ Sanmartín, R. 2006. El arte de morir. La puesta en escena de la muerte en un tratado del siglo $X V$ : 13-26 Madrid: Iberoamericana.

${ }^{33}$ García Fernández, M. 1996: 62-72.

34 APNP, notario Martín Pérez de Artázcoz, Asiáin, leg. 83bis, 20 de diciembre de 1687.

${ }^{35}$ APNP, notario Juan Arlegui, Pamplona, legajo 261, doc. 122bis. 
En cualquier caso, el linaje instrumentalizó las exequias funerarias dotándolas de una significación que trascendía el mero hecho religioso. Se creó una nueva vinculación entre la casa y la Iglesia que permitió la construcción de una amplia red de relaciones sociales y un nuevo lenguaje simbólico, aunque de temática mortuoria, del privilegio.

En los rituales funerarios, familia y posición estamental marcaban las diferencias en el marco comunitario a la hora de hacer frente al, igual para todos, tránsito de la muerte. Las exequias se convirtieron de esta manera en un pretexto más para dilucidar prerrogativas de rango y dignidad de cara a la comunidad. En la muerte, como en la vida, quedaban consagradas las diferencias sociales en el desarrollo de los funerales y en la última sepultura. ${ }^{36}$ La muerte se había transformado en un mecanismo más de preservación del modelo social existente. Los actos ritualizados garantizaban la reproducción social, interna y externa, del estamento privilegiado del Antiguo Régimen. ${ }^{37}$ En el ritual funerario quedaba traducida la estratificación social recibiendo el cadáver un tratamiento acorde con la posición gozada en vida.

La Muerte y la Fortuna, niveladores sociales desde el Medioevo, no desaparecieron durante la Edad Moderna. Su esquema de crítica social, ya representado en las danzas de la muerte, evolucionó hacia las dos grandes concepciones barrocas. Por un lado, la del mundo entendido como un gran teatro y por otro la del sueño como símbolo de la caducidad humana y pompa de su vanidad (Jara Fuente, 1996: 878).

Desde el siglo XVII el tránsito de la muerte fue abordado con un renovado sentido de la teatralidad, adoptando un carácter semifestivo. La exaltación del difunto y su piedad se manifestaban al igual que su poder en los cortejos fúnebres y funerales. ${ }^{38} \mathrm{El}$ ejemplo fueron todas las exequias reales celebradas en Navarra a lo largo de la Edad Moderna, donde el fausto, el ceremonial y la iconografía se unirían en un mismo lenguaje de exaltación del poder monárquico y de las figuras de los fallecidos. ${ }^{39}$ Según Varela todo este tipo de manifestacio-

\footnotetext{
${ }^{36}$ Campa, R. 2003. «Iglesia y religiosidad española según la condesa D’Aulnoy (segunda mitad del siglo XVII)», en M. B. Villar y P. Pezzi (eds.), Los extranjeros en la España moderna. Actas del I Coloquio Internacional: tomo II, 170. Málaga: [s.n.].

37 Jara, J. 1996. «Muerte, ceremonial y ritual funerario: procesos de cohesión intraestamental y de control social en la alta aristocracia del Antiguo Régimen (Corona de Castilla, siglos XV-XVIII)». Hispania 194: 861-864.

38 Bonet, A. 1990. Fiesta, poder y arquitectura. Aproximaciones al barroco español: 18-25 Madrid: Akal.

${ }^{39}$ Fernández Gracia, R. 1998. «El túmulo de Felipe II en la catedral de Pamplona». Actas del Congreso Internacional: Felipe II y las Artes: 453-464 y Azanza, J. J. y Molins, J. L. 2005. Ceremonial funerario, arte efímero y emblemática. Exequias reales del regimiento pamplonés en la Edad Moderna. Pamplona: Ayuntamiento de Pamplona.
} 
nes fúnebres poseían una carga emocional cuyo «desbordamiento afectivo se hallaba tan ritualizado o era tan obligatorio como su contrario».40

También los nobles navarros compaginaron las muestras de respeto y de honor con los responsos funerarios. Lo habitual en las exequias de los notables era la participación de un número indeterminado de niños, pobres o desfavorecidos con hachas y velas encendidas abriendo el cortejo funerario. Para evitar excesos en la utilización de este tipo de hachas, las Cortes de Pamplona de 1572 dispusieron que en ningún entierro, fuera cual fuera su condición, pudieran llevarse más de 4 hachones aunque dejaba absoluta libertad en el número de velas. ${ }^{41}$

A pesar de estas leyes, en 1685 la palaciana de Subízar dispuso que en sus funerales se llevaran «36 achas, 50 velas de a libra y 4 rollos de cera hilada de a 4 libras cada uno»..$^{42}$ En 1696, don Juan Piñeiro, en el acta de fundación de un convento senil en el lugar de Eriete señalaba que los ancianos ahí recogidos deberían acudir cada año a la procesión del Corpus Christi portando antorchas, que ofrecerían a los colegios jesuitas fundados por él mismo en Pamplona y Trápani a la par que orasen por su alma. ${ }^{43}$

La señora de los palacios de Esparza y Zariquiegui, doña Isabel de Subiza y Bernedo, viuda del señor don Pedro de Echeberz y Toro, que fue Alguacil Mayor del Reino, en 1690 firmaba sus últimas voluntades, como ya se mencionó, con suma humildad. En ellas aseguraba que su deseo era ser sepultada «cuando Nuestro Señor sea servido de sacarme de esta vida» y que su cuerpo fuera depositado en la iglesia de San Lorenzo de Pamplona en la tumba donde ya estaba enterrado su esposo y que se situara debajo de la tarima del altar. Asimismo pedía que sólo se pusieran en su entierro doce velas señalando que al entierro «hayan de concurrir y concurran los conventos y parroquias de esta ciudad y niños espositos y mi cuerpo se haya de enterrar dando la limosna habitual». ${ }^{44} \mathrm{La}$ presencia de los menores como 'grupo de edad' simbolizaba la continuidad de la vida a pesar de la muerte de los mayores..$^{45}$

Vemos que las ceremonias funerarias tenían como protagonista pasivo al difunto que, según García Bourrellier, «continuaba siendo un punto de referencia social incluso después de muerto». ${ }^{46}$ Para las elites de la Edad Moderna era pre-

\footnotetext{
40 Varela, J. 1990. La muerte del rey. El ceremonial funerario de la monarquía española (15001885): 31 Madrid: Turner.

${ }^{41} \mathrm{NR}, 3,16,4$.

${ }^{42}$ AGN, TT. RR., Procesos judiciales, 77796, fols. 5-6.

${ }^{43}$ ADP, C/545-n ${ }^{\circ} 15$.

${ }^{44}$ APNP, notario Juan Arlegui, Pamplona, leg. 261, doc. 122bis.

${ }^{45}$ Gittings, C. 1984. Death, burial and the individual in early modern England: 153-161 Londres: Helm.

${ }^{46}$ García Bourrellier, C. R. 1998: 547.
} 
cisa la presencia de la figura del pobre en los ritos funerarios de los miembros del estamento de caballeros. ${ }^{47}$

El necesitado, en estos funerales de las capas altas, servía para aliviar las tensiones que pudiera haber en relación con la salvación del alma del finado. Junto con los frailes pertenecientes a las órdenes mendicantes, los niños expósitos y los pobres que acompañaban los cortejos se habían convertido en verdaderos «especialistas de la muerte».

Así, en 1502 el señor de Sarría ordenó que se diera limosna además de a los clérigos, a los «estudiantes escolares y pobres que llegaran a las dichas mis honras». ${ }^{48} \mathrm{Y}$ el señor de Tirapu, Goñi y Peralta encargó que se vistiera a doce pobres «de paño pardillo» para que asistieran a su funeral. ${ }^{49}$ La señora de Echálaz encargó en 1568 que se dieran «ropetas de luto con sus caperuzas» a otra docena de necesitados para que acompañaran en sus funerales su cadáver portando velas..$^{50}$

El difunto para asegurar su salvación podía realizar una obra pía con los más necesitados dejando constancia de este deseo en el testamento. En ocasiones, este gesto de buena fe suponía la asistencia de algunos de ellos a sus honras fúnebres con objeto de que rezaran por su alma y a cambio se les daría una limosna, vestidos o comida. En ocasiones los testadores buscaban el honor de tener alrededor de su cadáver el mayor número posible de sacerdotes como manifestación de su influencia social. En compensación por su asistencia los clérigos recibían una limosna y una comida. Los sacerdotes que solían ser llamados, en el caso de los palacianos, solían ser los que ejercían como abades en los valles o comarcas donde se ubicaba el palacio.

En el siglo XVII el señor de Sarría celebró sus exequias en Oco. Las celebraciones duraron dos días y a ellas acudió toda la clerecía de la comarca cobrando cada uno un real por ello. A los 150 parientes y amigos se les sirvió de comer y cenar. En las misas por su alma celebradas en la parroquial los familiares, amigos, criados y una docena de pobres recibieron vestidos de luto. Así mismo, el 'pan añal' que se ofreció supuso 4 cargas de trigo. ${ }^{51}$

En 1636 los palacianos de Olloqui, en su testamento, convocaban a los sacerdotes de los lugares cercanos a su vivienda. ${ }^{52}$ En 1556 se prohibió en Navarra dar de comer a más de seis clérigos en los entierros, pero pocos años

\footnotetext{
${ }^{47}$ Barreiro, B. 1983. «La nobleza asturiana ante la vida y la muerte». Actas del II Coloquio de Metodología Histórica Aplicada. La documentación notarial y la Historia II: 39 y ss.

48 AGN, TT. RR., Procesos judiciales, 10842, fol. 288.

49 ADP, C/294-n ${ }^{\circ} 14$, fols. 90-101.

${ }^{50}$ ADP, C/ 148-n ${ }^{\circ} 2$, fols. 29-36.

51 Idoate, F. 1959. El Señorío de Sarría: 234 Pamplona: Gráficas Iruña.

52 AGN, TT. RR., Procesos judiciales, 102633, fol. 254v.
} 
después esta disposición era derogada con la única limitación de que no se les ofreciera de comida ave de ningún tipo y sí carnero, vaca, menudos, tocino o frutas. ${ }^{53} \mathrm{~A}$ pesar de ello, en el entierro de doña Francisca de Vicuña, señora de Eriete, celebrado en 1674 acudieron 49 sacerdotes pagándosele a cada uno 4 reales de limosna y convidándoles a un banquete funerario en el que se les dio carnero, cordero, huevos, frutas, queso, vino y aves. ${ }^{54}$

A estos medios de buscar la salvación del alma, la nobleza navarra añadió la selección de la sepultura, las bulas de difuntos o, sobre todo, la mortaja. A lo largo de la Edad Moderna existió un creciente interés por el uso de determinados hábitos religiosos a modo de sudario. Destacaban entre todos ellos los de las órdenes militares, mendicantes y especialmente el de los padres franciscanos. ${ }^{55} \mathrm{El}$ uso del hábito de San Francisco fue apoyado por la propia orden y por la multitud de indulgencias que le habían concedido papas como Nicolás IV, León X o Clemente VII para redimir las penas. ${ }^{56}$

El uso de estas prendas puede observarse en Navarra. El caso de la capital pamplonesa fue en cierto modo paradigmático. Hubo ejemplos en toda Navarra de disposiciones sobre hábitos. De los de Órdenes Militares, tenemos el ejemplo del maestre de campo don Francisco de Sarabia, quien señalaba en su testamento de 1680 que deseaba ser enterrado con el hábito de la Orden de Santiago del que era portador «como se estila y acostumbra en la Iglesia o convento que tuviere voluntad, dispusiese y ordenare la señora doña Mariana Balanza, su mujer" ${ }^{57}$ El señor del palacio de Jarola, en Elbetea, dieciséis años después apuntaba que deseaba tomar sepultura vestido con el mismo hábito. ${ }^{58}$

En cuanto a los mantos religiosos, fueron escasísimos los nobles navarros que realizaron su solicitud en sus testamentos. Se puede mencionar la petición de doña Mariana Ruiz de Vergara, señora de Góngora, que pidió ser enterrada con el hábito de Santa Clara, si era sepultada en la iglesia del lugar de su palacio, o con el de Nuestra Señora del Carmen si moría en Pamplona y su tumba se alojaba en el convento de las Carmelitas Descalzas de la ciudad.

El manto franciscano fue el elegido por el señor del palacio de Elcarte en 1614 al igual que por los de Lapuzáin un año más tarde, o por la señora de Erie-

${ }^{53} \mathrm{NR}, 3,16,1$ y 7.

${ }^{54}$ AGN, TT. RR., Procesos judiciales, 31857 , fol. 77v-78.

${ }_{55}$ Rodríguez Sánchez, A. 1994. «La muerte en España: del miedo a la resignación», en E. Serrano Martín (ed.), Muerte, religiosidad y cultura popular, siglos XIII-XVIII: 51-52. Zaragoza: Institución Fernando el Católico.

${ }_{56}^{56}$ Madariaga, J. 1998. Una noble señora, herio anderea: actitudes ante la muerte en el País Vasco: 168-174 Bilbao: UPV-EHU.

${ }^{57}$ APNP, notario Juan Arlegui, Pamplona, caja 19385/2, leg. 259, doc. 87, 13 de junio de 1680.

${ }^{58}$ APNP, notario Juan de Echeverz, Elizondo, leg. 93, 27 de noviembre de 1696. 
te en 1674 y doña Isabel de Subiza, señora de los palacios de Esparza y Zariquiegui en 1690.59

En definitiva, en el seno de una sociedad jerarquizada como la del Antiguo Régimen, la muerte de uno de sus miembros requería la participación de todos en la exorcización de los demonios que acechaban el alma del fallecido. Esto era necesario además para la revertebración del modelo de articulación social.

El ceremonial funerario debía cumplir una doble misión. Por un lado, ser un referente simbólico de primer grado. En él el individuo era capaz de comprender la muerte como una clara manifestación de la naturaleza humana. En segundo grado, dejaba patente que, si bien todas las almas eran iguales a los ojos de Dios, no así los cuerpos, que se mostraban más o menos agraciados según su origen de nacimiento estamental. Por último un referente simbólico de tercer grado era el que sancionaba la sucesión en el seno del linaje.

Es decir, el sentido natural de la muerte había sido transformado en una cosmovisión de la existencia humana propia del seno de cualquier sociedad de privilegios. A la muerte como ‘extinción' se unía la sucesión como continuidad. Y junto a todo ello, la legitimación del privilegio y la reproducción sociológica del poder de las elites dominantes. Se observa pues cómo con la muerte se mantenía la idea del control social, además de reflejar otros fines propagandísticos o de mantenimiento de la memoria del linaje. Todos estos aspectos cobraron una gran relevancia durante el Antiguo Régimen a través de la fundación de obras pías, capellanías y otras celebraciones de aniversario. ${ }^{60}$

\section{OBRAS PÍAS Y CAPELLANÍAS}

Para Aberlardo Levaggi, una capellanía es una «fundación instituida generalmente a perpetuidad, por vía testamentaria o acto entre vivos, en virtud de la cual el fundador afectaba un bien inmueble o una suma de dinero situada sobre un bien inmueble, para costear con su renta la celebración de misas u otros actos píos y beneficiar a determinadas personas o instituciones; a título de patrimonio si estas personas aspiraban al sacerdocio, o el título de patronos o capellanes». ${ }^{61}$

\footnotetext{
${ }^{59}$ Noáin, J. J. 2003. Nobleza media de Navarra en la Edad Moderna. Régimen señorial, familia, mentalidad, (siglos XVI-XVII): 354 Pamplona: Tesis inédita.

${ }^{60}$ Díaz, J. 2003. «Prestigio social del estamento nobiliario: el patronazgo eclesiástico asturiano de los Vigil de Quiñones en el siglo XVII». Revista de Historia Moderna 21: 274.

${ }^{61}$ Levaggi, A. 1992. Las capellanías en Argentina. Estudio histórico-jurídico: 21 Buenos Aires: UBA y Barrio Gozalo, M. 1982. Estudio socio-económico de la Iglesia de Segovia en el siglo XVIII. Segovia: Caja de Ahorros y Monte de Piedad de Segovia
} 
Fue esta una práctica habitual entre las elites con posibilidades económicas durante el Antiguo Régimen. ${ }^{62}$

La fundación implicaba un lado material y otro espiritual. ${ }^{63} \mathrm{Su}$ fin era celebrar misas por el difunto fundador a la par que conceder un «digno pasar» a un eclesiástico de su familia. En muchos de estos casos la figura de capellán se transformaba en un cargo hereditario dentro del linaje familiar. ${ }^{64} \mathrm{El}$ fundador, tras designar al capellán, nombraba un patrono, normalmente miembro de su casa. Disponía además el dinero destinado a la manutención del capellán mediante la entrega de diferentes censos consignatarios. ${ }^{65}$ Ese dinero debía de producir unas rentas anuales destinadas a la congrua y al pago de limosnas para cada una de las misas encargadas. ${ }^{66}$ Había unos bienes sujetos a ciertas obligaciones de mantenimiento de estas fundaciones que formaban parte de los beneficios eclesiásticos.

La capellanía era una institución multifacética con diferentes tipos y clasificaciones. ${ }^{67}$ Las fundaciones se creaban en vida o poco antes de morir y los mecanismos para llevarlas a cabo eran el contrato o el testamento. Entre ambos el medio más usual era el testamento y suponía una muestra de devoción expiatoria. Es decir, en ellos se «disponían de las cosas relacionadas al descargo de su conciencia y bien de su alma».68

\footnotetext{
62 Este tipo de instituciones se trasladaron sin problema alguno desde la Península a los territorios de ultramar bajo dominio de la Monarquía Hispánica desde las Indias a Filipinas. Wobeser, G. 1998. «La fundación de capellanías de misas, una costumbre arraigada entre las familias novohispanas: siglos XVI-XVIII». Jahrbuch für Geschichte Lateinamerikas 35: 25-44 y Mesquida, J. 2010. «La población de Manila y las capellanías de misas de los españoles: libro de registros, 1642-1672». Revista de Indias 249: 469-500.

${ }^{63}$ Castro, C. Calvo, M. y Granado, S. 2007. «Las capellanías en los siglos XVII-CVIII a través del estudio de su escritura de fundación». Anuario de Historia de la Educación XVI: 335-347.

${ }^{64}$ Soria, E. 2002. «Las capellanías en la Castilla moderna: familia y ascenso social», en A. Irigoyen y A. L. Pérez (eds.), Familia, transmisión y perpetuación (siglos XVI-XIX): 137-139. Murcia: Universidad de Murcia.

${ }^{65} \mathrm{Si}$ las capellanías eran de carácter familiar o de 'sangre' se solían beneficiar directamente las propiedades. Barrio Gozalo, M. 1992. «Las condiciones materiales del clero parroquial del obispado de Segovia en el siglo XVIII (II): la realidad de los ingresos y los gastos». Investigaciones históricas: Época moderna y contemporánea 12: 119 y Pro Ruiz, J. 1988. «Tratamiento de las capellanías en los estudios de historia de la propiedad de la tierra en Castilla». I Congreso de Historia de Castilla-La Mancha. Conflictos sociales y evolución económica en la Edad Moderna 8: 327-330. En numerosas ocasiones estas propiedades eran tierras de labor y en especial viñedos. Arroyo, J.L. 2007. «Capellanías de la vicaría de Viana». Cuadernos del Marqués de San Adrián 5: 39-90.

${ }^{66}$ Zabalza, A. et alii. 1994. Navarra 1500-1850 (Trayectoria de una sociedad olvidada): 64 Pamplona: Ediciones y Libros.

${ }^{67}$ Pro Ruiz, J. 1989. «Las capellanías. Familia, iglesia y propiedad en el Antiguo Régimen». Hispania Sacra 84: 585-602.

${ }^{68}$ Montero, C. 1998. «La capellanía: una de las prácticas religiosas para el más allá», en Má. P. Martínez, G. Von Wobeser y J. G. Muñoz (coords), Cofradías, capellanías y obras pías en la América Colonial: 134. México: Universidad Nacional Autónoma de México.
} 
Debe tenerse en cuenta que durante la Edad Moderna en el indoctrinamiento de la población con gran frecuencia aparecían las penas que sufrían las almas en el Infierno y el Purgatorio. ${ }^{69}$ Fundar la capellanía garantizaba la perpetuación de las misas a favor del difunto. Por eso, en la mayoría de las fundaciones, se menciona la ayuda a las almas del Purgatorio con diferentes fórmulas de intercesión. Se añadían también otros motivos como el aumento del culto divino, la honra de Dios, de la Trinidad, de la Virgen o de un santo.

En la fundación de una capellanía de Domingo de Monreal en Santa María de Tudela en 1648, el testador señalaba que quien «tome posesión de la dicha capellanía haciendo para ello las ceremonias de estilo y verificado pueda administrar y administrare las fincas de ellas arrendándolas a las personas por los tiempos, precios y condiciones que le pareciere percibiendo y cobrando lo que precediere a los tales arrendatarios». ${ }^{70}$

Entre los varios elementos de la capellanía los más importantes eran siempre los espirituales. En la cultura religiosa del Antiguo Régimen, de acuerdo con el principio teológico de la comunión de los santos, toda manda pía realizada en la tierra por un miembro de la Iglesia militante beneficia a los de la purgante para que puedan acceder a la Iglesia triunfante, cuyos miembros ruegan a su vez por los vivos.

A principios del siglo XVII, Alonso Pérez de Lara señalaba que todo pecador arrepentido y confeso «queda libre de la culpa mortal y pena eterna que le correspondía, pero deudor de la temporal que ha de pagar, y satisfacer por sus pecados a la justicia divina, y si hace satisfacción en esta vida por obras penales

\footnotetext{
${ }^{69}$ Portús, J. y Vega, J. 1998. La estampa religiosa en la España del Antiguo Régimen: 216 Madrid: Fundación Universitaria Española y Portús, J. 2004. «Infiernos pintados: iconografía infernal en la Edad Moderna hispánica», en M. Tausiet y J. S. Amelang (eds.), El Diablo en la Edad Moderna: 258. Madrid. Marcial Pons. Pongamos por ejemplo la labor misionera del jesuita Jerónimo López que desarrolló su apostolado en las décadas centrales del siglo XVII por tierras de Castilla, Aragón y Navarra. En sus predicaciones, nos narra su biógrafo, usaba con frecuencia calaveras y cuadros con almas condenadas «en medio de llamas, rodeada de demonios, que en figuras de bestias fieras la están atormentando crudelísimamente». El autor señala que en Salamanca tras uno de los sermones de este predicador «la emoción que hubo en la última parroquia, cuando mostró al auditorio el retrato de un alma condenada fue muy extraordinaria; a la vista de tan horrible y espantosa figura quedaron no menos asombrados que aprovechados» Marín, J. 1682. Vida, virtudes, y misiones del venerable P. Jerónimo López misionero apostólico de la Compañía de Iesús de la provincia de Aragón: 135 y 141 Roma: Varesio. Igualmente hacía el también miembro de la Compañía de Jesús San Pedro Claver, que se postraba para oír las confesiones de los fieles en Cuaresma con imágenes de almas en pena purgando sus pecados que «movían provechosos afectos en los penitentes, para llorar sus culpas» Fernández, I. 1666. Apostólica y penitente vida del V. P. Pedro Claver, de la Compañía de Iesus: 236 Zaragoza: Juan María Sola.

${ }^{70}$ Archivo Histórico de Tudela [AHT]-Archivo del Marqués de San Adrián [AMSA], General, leg. 4bis, 11 .
} 
y satisfactorias, queda libre de la pena de Purgatorio y no haciéndola, la ha de purgar en él, y no salir hasta pagar el último cuadrante». ${ }^{71}$

Durante esta época, las personas con esta mentalidad encontraban muchas posibilidades para abreviar su estadía en el Purgatorio y la de sus deudos y acreedores. Las mejores eran la misa y el ayuno, «que servían para reparar pecados propios y de terceros y no para obtener la salvación, por lo que constituían el objetivo espiritual tanto de capellanías como de cofradías, bulas [de Santa Cruzada], indulgencias y obras pías en general». ${ }^{72}$

Debemos entender pues la capellanía como intercesora de los propios fundadores para salvar sus almas y reducir su estancia en el Purgatorio. Se trataba, según José Francisco López, de «una hipoteca espiritual y eterna, como el alma del fundador que sigue disfrutando en la otra vida, los intereses espiritualizados en forma de misas -especie de telégrafo místico que transmite los valores de ésta a los moradores de aquélla, como otras tantas de crédito expiatorio, con que ellos desean satisfacer las cuentas de sus deudas ante Dios, y obtener su remisión». ${ }^{73}$

La misa no se compraba pues, en palabras de Mercado, (1571: 97), «excede a todo el oro terreno [...] Siempre se dice la misa gratis de entrambas partes, del celebrante y del pidiente, que la limosna acostumbrada, limosna es, y sustentación del ministro, no precio. Mas obligarse el sacerdote a celebrar mucho tiempo en una cierta iglesia, o en una particular capilla, o por una persona nombrada viva o difunta, esta obligación distantísima es de su misa u oficio divino, cargo que él se pone y puede vender y concertarse y regatear su precio, como se hace en las capellanías [...] es obligación civil, humana no divina ni sacra, y por consiguiente de valor».

Las cantidades entregadas como limosna por estos servicios religiosos fueron de lo más variado en la fundación de capellanías nobiliarias en la Navarra del Antiguo Régimen. En 1518 los palacianos de Arazuri dispusieron la celebración de tres misas semanales a perpetuidad que deberían oficiarse los lunes, viernes y sábados por sus ánimas y por las de sus antepasados. Con tal fin, destinaron 4 cahíces de trigo anuales provenientes de los lugares de Cía y Eguíllor a lo que sumaron la pecha de Otazu, consistente en tres robos de trigo anuales. ${ }^{74}$

En 1558 el señor del palacio de Artázcoz tuvo que destinar nueve cahíces de trigo anuales que poseía en Labiano para la celebración de tres misas semana-

\footnotetext{
${ }^{71}$ Pérez de Lara, A. 1733. Opera omnia: prólogo Lyon: Hermanos Deville.

${ }^{72}$ Muñoz, J. G. 1998. «Las estrategias de una elite frente a la Tierra y el Cielo: capellanías en Colchagua en el siglo XVII», en Ma. P. Martínez, G. Von Wobeser y J. G. Muñoz (coords.), Cofradías, capellanías y obras pías en la América Colonial: 159. Universidad Nacional Autónoma de México.

${ }^{73}$ Levaggi A. 1992: 21.

${ }^{74}$ AGN, TT. RR., Procesos judiciales, 28035 fol. 59.
} 
les, más otras dos cantadas de réquiem por año en su capellanía. ${ }^{75}$ En 1690 el marqués de San Adrián, don Pedro Magallón y Vergara, y su esposa doña María Beaumont y Navarra pusieron a su vez a censo 1.500 ducados al $3 \%$ a favor de una capellanía. Ésta se otorgaba al guipuzcoano don Domingo de Atocha, natural de San Sebastián, que era caballero de la Orden de Santiago además de palaciano de la casa-torre de Zubieta. En 1762 el capellán Pello Ayanz de Ureta reclamaba los réditos que debían derivarse de esos 1.500 ducados para poder cobrar su paga. ${ }^{76}$

La capellanía, al igual que otras muestras de religiosidad como las propias obras pías, era una práctica más del Arte de buen morir desarrollado en la sociedad de la Edad Moderna. En este caso, una práctica individual y no colectiva pero inscrita dentro de la reforma religiosa en la Europa católica tras el Concilio de Trento. El propio fundador establecía las condiciones de la capellanía ya que la dotaba económicamente y nombraba a su primer capellán y al encargado de su gobierno, el patrono. Los capellanes sólo sacaban beneficio de los réditos o intereses. El principal o capital invariable seguía manteniendo perpetuamente otras muchas misas y el superávit favorecía a otras almas según el orden de sucesión en los cargos establecido por el fundador.

Así por ejemplo, los condes de Lodosa poseían en 1644 una capellanía en el convento de San Francisco de Tudela con una renta de 200 reales anuales. ${ }^{77}$ El testador solía disponer a su vez las intenciones de las misas que se celebraran y el número de veces y fechas en que esto ocurriría a lo largo del año. El marqués de Cortes poseía una capellanía en la iglesia de San Pedro de la Rua de Estella. Tal era su importancia que contaba con nueve capellanes que se turnaban para celebrar las misas diarias. Los palacianos de Lepuzáin destinaron en 1615 un censal de 200 ducados al 5\% anual para fundar una capellanía que les ofreciera dos misas semanales. ${ }^{78}$

Según el Diccionario razonado de legislación de Joaquín Escriche (1831), la voz 'patrón' responde al sujeto «que tiene derecho de patronato» y "patronato' al «derecho de presentar sujeto para que se le confiera algún beneficio eclesiástico; o bien: un derecho honorífico, oneroso y útil que compete a uno en alguna iglesia por haberla fundado, construido o dotado con consentimiento del obispo, o por haberle heredado de sus predecesores que lo hicieron». Sobre la persona del patrono recaía la responsabilidad de la continuidad de la institución fundada, que dependía del celo y la diligencia que éste prestase en su mantenimiento y en el logro de los fines propuestos por el fundador.

\footnotetext{
75 AGN, TT. RR., Procesos judiciales, 15998, fol. 7.

76 AHT-AMSA, General, sig. 5, caja 3, n 1 , fol. 85.

77 AGN, TT. RR., Procesos judiciales, Iruñela, 1656, $\mathrm{n}^{\circ} 13$, fol. 9r.

78 ADP, C/302-n ${ }^{\circ}$, fols. 17-24.
} 
Hay que tener en cuenta el papel polivalente de estas instituciones en la sociedad tradicional de los siglos XVI, XVII y XVIII ${ }^{79}$. El patronato debía cumplir por una parte con una labor asistencial de las aspiraciones espirituales del benefactor y por otra con aspiraciones materiales de algunos miembros del linaje de éste. Es decir, había que saber respetar las últimas voluntades del antepasado creador de la capellanía y adecuar ésta a los cambios y a la economía de la casa debido al carácter crediticio de su sustento.

Un caso contrario se dio en 1599 cuando el cura de almas demandaba a Esteban de Orísoain y Torres, señor de Laboa, y a su esposa Joana de Torres exigiendo que se cumpliera la última voluntad de la abuela de la palaciana, doña María Garcés. La noble había dejado en sus últimas voluntades el mandato de fundar una capellanía en la catedral pamplonesa, poniendo como patrón a Esteban de Orísoain, esposo de su nieta, heredera y nueva señora de Laboa. Los herederos recogieron en cambio los bienes de la difunta en el pueblo de Espinal y los pusieron a censo sin fundar la capellanía. Según el cura de almas, ambos «antes más de seis años gozan de los dichos corridos juntamente con los demás bienes sin cumplir el testamento de la dicha María Garcés». ${ }^{80}$ El procurador de los acusados reprocha por contra la actitud del cura de almas ya que según él su representado sólo había desarrollado diferentes maneras de gestionar esos caudales para hacer posible una mejor fundación de la capellanía. A su vez señalaba que ya se habían efectuado algunas de las misas prescritas en favor del alma de la testadora. Sin embargo, el cura de almas dudaba de las buenas intenciones de los palacianos ya que aseguraba que esas misas habían sido cuestión de más deseos de María. Y que estos servicios debían ir parejos al de la fundación de la capellanía. Así mismo, no tardó en recordarles que aún quedaban por decir algunas de esas misas encargadas. ${ }^{81}$

En 1605 los patronos de la capellanía fundada en Asiáin por don Miguel de Asiáin, abad del lugar de Zizur Mayor, expusieron que la casa sobre la que se había fundado estaba derruida y las piezas y viñas incultas. Solicitaban por ello licencia para venderlas. Tras concederles el permiso estas propiedades se remataron en 254 ducados a Miguel de Anoz, alcaide del palacio de Asiáin. Al cabo de un tiempo el fiscal pleiteó contra el comprador debido a que no había ofrecido las debidas garantías, ya que todo se puso a disposición de venta pero con un crédito del $6 \%$ al año sobre los 254 ducados. ${ }^{82}$

\footnotetext{
${ }^{79}$ Calvi, M. 2007. «La capellanía: una forma rinnovata di assistenza spirituale». Quaderni di diritto ecclesiale vol. 20, 3: 227-239 y Escudeo, Fco. J. 2003. «Cofradías, capellanías y patronazgos (s. XV-XVI)», en $\mathrm{M}^{\mathrm{a}}$. Dolores Zaldívar (coord.), I Jornadas de Patrimonio Religioso de la Villa de Socuéllamos: 41-62.: Ayuntamiento de Socuéllamos.

${ }^{80}$ ADP, C/220-n 31 , fols. $4-8$.

${ }^{81}$ Ibídem, fols. 45-57.

${ }^{82} \mathrm{ADP}, \mathrm{C} / 424-\mathrm{n}^{\circ} 5$, fol. 43.
} 
En 1684 en Pamplona el cura de almas exigía a doña Teresa de Rada, viuda y heredera de don Martín Cruzat y Góngora que había sido señor de Óriz y Góngora, que entregara la donación de bienes hecha por el tío de su difunto esposo. El donante, prior de Roncesvalles y de la Seo pamplonesa, había entregado a don Martín sus propiedades con la condición de fundar una capellanía de 2.000 ducados pero el sobrino murió sin haber consignado las cantidades. ${ }^{83}$

En 1684 el presbítero Antonio de Lana y Mendoza era capellán de la fundación del difunto don Antonio López de Mirafuentes. Éste, además de su primo, había sido caballero de la Orden de Santiago y había creado una capellanía en 1658 con intención de que se celebrara misa a las doce del medio día todos los días de fiesta. Así mismo, había ordenado que se vendiera su hacienda para costear los gastos y que, cuando con ese dinero «no llegase para más, se ciña a lo que llegase». Las cantidades eran lo suficientemente grandes como para que don Antonio descansase en paz puesto que sólo la venta de las viñas había aportado unos trece mil ducados de plata ${ }^{84}$ El demandante y capellán sospechaba que la familia se había quedado con gran parte del beneficio de la venta de los bienes del difunto, por lo que los llevaba a los tribunales navarros. Los acusados eran doña Casilda Garcés, viuda del anterior patrono de la capellanía, don Juan de Unda, y el hijo de ésta, don Miguel de Unda, caballero de la Orden de Calatrava.

Se dio el nombre de 'patronatos de legos' a aquéllos cuya posesión estaba reservada a los laicos con la facultad de nombrar y renovar a su voluntad al capellán. La carga o gravamen que éste debería cumplir serían las obligaciones impuestas por el fundador a cambio de los emolumentos obtenidos por el cargo de capellán. Estas capillas laicales no funcionaron como título de órdenes ya que el propósito benéfico de los fundadores se desvió en gran medida de la persona del capellán a la del patrono como principal favorecido desde el punto de vista económico.

La pequeña nobleza, los hidalgos, eran con frecuencia los principales poseedores de capellanías de carácter patrimonial. Esto se debía a que anejas a estas fundaciones había un interés de tipo material mucho más acentuado. ${ }^{85}$ Este tipo de patronatos de legos era, según Antonio Domínguez Ortiz, una pervivencia medieval mayoritariamente extendida en los territorios arcaizantes del norte de la Península Ibérica.

En la catedral pamplonesa, las capellanías del coro no eran «contatibas» sino «legas de renta anual» y una de ellas pertenecía a don Juan de Armendáriz con un censo de 250 ducados de plata. ${ }^{86}$ Del resto no se expresan los nombres y apellidos de las raciones y capellanías del coro porque los sujetos que las obtu-

\footnotetext{
${ }^{83} \mathrm{ADP}, \mathrm{C} / 938-\mathrm{n}^{\circ} 1$.

${ }^{84}$ AGN, TT. RR., Procesos judiciales, 31719, fol. 248.

85 Díaz, J. 2003: 264.

86 Domínguez Ortiz, A. 1979. Las clases privilegiadas en el Antiguo Régimen: 252 Madrid: Istmo.
} 
vieron no lo hicieron como beneficios derechos «sino oficios y tocan al cabildo su nombramiento».87

Se pueden distinguir durante el Antiguo Régimen diferentes motivaciones para fundar una capellanía. Además de asegurar una renta pía para el futuro espiritual o lejano, ayudaba a descargar la conciencia y reparar cualquier injusticia, fundándola en beneficio del alma del acreedor. En 1565 Juan Piñeiro, palaciano de Eriete, dispuso que su heredero fundara cinco capellanías en la iglesia del lugar por el alma del testador, la de su abuela, madre y hermana. ${ }^{88}$ Podía desearse beneficiar una devoción concreta, mantener el culto divino en un lugar determinado o en una capilla familiar. Los palacianos de Redín establecieron en la iglesia del lugar dos capellanías en 1510.89

Otro de los fines era facilitar el acceso a este culto divino a determinados miembros de la población y destacar la conmemoración de días del año elegidos para la celebración de los oficios y las devociones predilectas de los testadores. En 1593 doña Catalina de Ezpeleta, palaciana de Elio, Esparza y Artieda, fundaba una capellanía usando 200 ducados de sus arras para que se le dijera una misa de Nuestra Señora cada sábado a perpetuidad y otras dos misas semanales en los Carmelitas Descalzos de Pamplona en base a 100 ducados de un censal. ${ }^{90}$

En 1615 el palaciano de Echálaz fundaba una capellanía en la capilla de Nuestra Señora del Rosario del convento de los dominicos de la capital del reino navarro para la celebración de dos misas semanales. ${ }^{91}$

Otras capellanías fueron instituidas como pago de una promesa o manda pía. En la parroquial de San Nicolás de Pamplona fundó una el indiano Pedro de Echálaz. Éste dejó claramente señalada en sus últimas voluntades la finalidad última de la institución en una cláusula del testamento que otorgó en las Indias. Debía crear «ciertas donaciones de doncellas huérfanas y pobres y para cierta capellanía o capellanías y otras fundaciones pías».92

Todas ellas posibilitaban el acceso al sacerdocio a algún familiar o deudo con las rentas suficientes para su manutención. Rentas que también llegarían a quienes fuesen designados como patronos. Esto permitía dejar algunas tierras o bienes con el gravamen a un legatario, con potestad o no de traspasar dicho derecho, de redimirlo o con el de simple renuncia. En 1686 se dio un caso curioso a causa de la vacante del cargo de capellán de la capellanía fundada en Elorz

\footnotetext{
${ }^{87}$ ADP, Libro de apuntamientos y curiosas útiles advertencias sobre patronatos, 1753, fols. 1-6. ${ }^{88}$ ADP, C/545-n ${ }^{\circ} 15$, fols. 101-120.

${ }^{89}$ AGN, TT. RR., Procesos judiciales, 73009, fol. 40v.

90 AGN, TT. RR., Procesos judiciales, 58574, fol. 418v.

${ }^{91}$ ADP, C/783-n ${ }^{\circ}$ 26, fols. 36-44.

92 ADP, C/1316-n 1 , fol. 39.
} 
por Juan de Elorz, vicario del lugar, y su sobrino Miguel. Ya en 1652 el puesto había quedado libre tras la muerte de su poseedor Sancho de Iriarte. En aquella ocasión quisieron hacerse con el cargo Esteban de Ibarrola, hijo de la casa Charlesenea de Elorz, y Martín de Yárnoz, cuyo padre era el dueño de la casa del escribano del pueblo que era, a su vez, la nativa de los fundadores de la capellanía. En 1683 el puesto de capellán volvió a quedar disponible tras morir Martín que lo había adquirido. Volvieron entonces a enfrentarse ambas familias igual que en 1652 al pretender ser capellán por un lado Lucas de Ibarrola, clérigo de la casa de Charlesenea, y Diego de Aldunate y Yárnoz, clérigo natural de Redín y descendiente de la casa del escribano de Elorz. Se le adjudicó a este, tras exigirse que «los sobredichos pongan cada uno y preséntenos su demanda con distinción del parentesco, y otro por qué les pertenece la dicha capellanía y de quién sea el patrón legítimo para proveerla y lo cumplan para la primera audiencia [...] presentando para este efecto la fundación; y testamentos de los testadores y para que se abrevie su provisión y las almas de los difuntos sin retardación gocen de los sufragios de las misas que están sin celebrarse desde la vacante, se comuniquen para ello al fiscal y cura de almas los autos y para la defensa de los derechos de la dignidad episcopal, que puedan pertenecerle en la provisión de dicha capellanía». ${ }^{93}$

Con este sistema de herencias de cargo vacantes vía línea familiar, se facilitaba a un tercero el acceso a la propiedad de un bien de producción. ${ }^{94}$ En 1689 Juan Antonio de Rada y su mujer Francisca Antonia de Eraso, palacianos de Subiza, pidieron licencia para tomar a censo 800 ducados pertenecientes a la capellanía de Antonio de Zozaya. El Real Consejo se la dio hipotecando para ello los bienes raíces de su mayorazgo con sus propiedades sitas en Muruarte, Subiza y Tiebas. ${ }^{95}$

En 1696 el dueño del palacio de Escároz, pidió licencia para tomar a censo 100 ducados de la capellanía fundada por don Gabriel de Esparza, obispo de Calahorra. Don Juan de Esparza, palaciano de Oronz, Ciz y Escároz afirmaba que en «el Depósito General y Arca de tres llaves de este Reino se hallan depositados cien ducados, pertenecientes a una de las capellanías que mandó fundar el Ilustrísimo y Reverendo Señor don Gabriel Esparza, obispo que fue de Calahorra, cuya patrona es doña Josefa de Esparza y capellán don Luis de Esparza y Artieda, clérigo de menores órdenes y mi parte desea tomarlos a censo a razón de cuatro por ciento sobre los bienes contenidos y expresados en el rol que presenta los cuales son propios de mi parte en propiedad y posesión sin parte derecho ni concurso de otra persona. Libres de toda carga de censo, pecha, venta,

\footnotetext{
93 ADP, C/1319-nº 11, fol. 15a.

94 Muñoz, J. G. 1998: 163-165.

${ }^{95} \mathrm{ADP}, \mathrm{C} / 1327-\mathrm{n}^{\circ} 5$.
} 
aniversario, capellanía, llamamiento, ni otro deber alguno y son seguros, ciertos, valiosos y cuantiosos para la seguridad de los dichos cien ducados y paga de sus réditos y aun parte mucho más valen en propiedad y venzan en cada un año las cantidades que expresaran». La respuesta fue favorable a don Juan, que se vio obligado a hipotecar una casa y su hacienda que poseía en San Martín de Unx para poder disfrutar de los bienes de la capellanía. ${ }^{96}$

Podían también ser refundadas como lo fue la sita en la iglesia de San Miguel de Lodosa, erigida por María de Mendoza. Su nieto don Godofre de Mendoza, conde de Lodosa, en 1605 pidió en su testamento que se indagara de qué piezas constaba y que posteriormente fuese refundada. ${ }^{97}$

Como se ve, las capellanías, además de una forma de religiosidad, era una manera de ofrecer un futuro seguro a los parientes segundones. ${ }^{98}$ Suponían un modo de adquirir prestigio en la comunidad, mediante una inversión de capitales destinados a asegurar una renta fija.

El momento álgido de este tipo de sufragios de tiempo largo fue la segunda mitad del siglo XVI y la primera del XVII. A partir de 1650 se produjo un descenso del número de estas fundaciones, no tanto debido a transformaciones de la sensibilidad religiosa, como a la menor capacidad de sostenimiento económico de las mismas. Los censos que suponía su creación resultaban excesivamente gravosos a la hora de facilitar la sucesión de los descendientes.

En 1605 el cura de almas demandaba al palaciano de Juarbe, don Pedro de Juarbe. Éste había fundado en 1584 una capellanía en a parroquial apoyándose en 150 ducados puestos a censo sobre doña Juana Cruzat y su hijo Martín Cruzat. Transcurridos varios años los Cruzat habían redimido el censo pero Juarbe no volvió a colocar el capital ni a pagar la capellanía, por lo que fue demandado. Alegaba en su defensa haberle nacido catorce hijos y «por ello se revocó la asignación a la capellanía». De igual manera, aseguraba que tras fundarla había tenido demasiado trabajo así como «enfermedades y necesidades y por esta causa y no tiene otra». Concluía su defensa afirmando que no le era posible pagar los 150 ducados asignados porque «aunque venda toda su hacienda apenas se sacarán otros tantos por ser de poco valor y en montaña». 99

Las capellanías eran transmisibles, como cualquier otro bien material de la familia e incluso podían llegar por vía hereditaria o matrimonial. Los propios marqueses de Santacara, Lope Beaumont de Navarra Díez Aux Armendáriz y

${ }^{96}$ ADP, C/1351-n ${ }^{\circ} 10$, fol. 1.

${ }^{97}$ AGN, TT. RR., Procesos judiciales, 309829.

98 Usunáriz, J. M ${ }^{\text {a }}$. 1991. «Un aspecto de la emigración navarra hacia el Nuevo Mundo durante el siglo XVIII: las remesas indianas». Segundo Congreso General de Historia de Navarra. 2. Comunicaciones, Príncipe de Viana, anejo 13: 383-392.

${ }^{99}$ ADP, C/424-n 46 , fols. 2-3. 
su esposa María Manrique Mesía, a su vez vizcondes de Castejón, ostentaban en 1691 el cargo de patrones de la capellanía familiar de la parroquia de San Jaime de Tudela. Se la entregaron posteriormente como herencia a su hijo Lope Beaumont y Manrique. En 1692 los marqueses recibieron a su vez el patronato de otra capellanía fundada por sus familiares don Diego de Peralta Beaumont y Frías y su consorte Úrsula de Vera y Medrano. ${ }^{100}$

Los marqueses de Falces eran patronos de una capellanía existente en la parroquial de este lugar. Tras sus desavenencias matrimoniales tuvieron que llegar al acuerdo de proveer los oficios alternativamente cada año. ${ }^{101}$ En 1606 en Echalar los señores del palacio de Gaztelu pusieron 100 ducados a censo para fundar una capellanía cuyo número de misas debían fijar sus herederos. ${ }^{102}$

Las capellanías pueden ser consideradas parte del sentir religioso de una elite social que respondía a sus necesidades espirituales y materiales. Por un lado, este grupo daba gracias a Dios e intercedía por su alma en pena, a la par que sostenía a diferentes miembros de la familia. El buscar una estancia corta en el Purgatorio formaba parte de este aprendizaje, por lo que se buscaba garantizar la ofrenda de misas para una salvación más pronta y como recuerdo en el linaje familiar.

En 1696 destinó 1.000 ducados don Miguel de Vergara, palaciano de Jarola, para que se fundara con sus réditos en la localidad baztanesa de Elbetea, donde estaba su casa, una capellanía. En ella se deberían celebrar 9 misas anuales a favor no sólo de su alma sino también de las de sus parientes. ${ }^{103}$

Años antes, en 1605 la mujer del difunto señor de Góngora, San Adrián, Ciordia, Dicastillo y Laguardia, doña María Ruiz de Vergara, que estaba enferma «pero en muy buen juicio» y veía acercarse la muerte, afirmó entender «que es cosa natural a toda persona viviente en este mundo». En aquellos instantes decidió a hacer testamento «porque después de mis días no haya pleitos ni cuestiones entre mis hijos ni otras personas». De esta manera, y revocando previamente los codicilos anteriores, pidió un sufragio a favor de su alma, la de su difunto esposo y los antepasados de éste así como para los sucesores suyos del palacio. Con tal fin ordenó que se fundara en la iglesia de Góngora una capellanía para ello «ad nutum ad mobiles y no titular de misas rezadas». Tales servicios deberían cumplirse en días festivos de guardar y domingos y el titular sería nombrado por su sucesor en la casa y palacio de Góngora. Para sufragar los gastos destinaba 400 ducados «de principal» al $6 \%$ puestos a censo sobre los bienes que poseía en Pamplona y los de Muruarte de Reta «que se darán como limosna en sales».

${ }^{100}$ Arrese, J. L. 1977. Colección de biografías locales: 138 y 424 San Sebastián: Industria Gráfica Valverde.

101 AGN, TT. RR., Procesos judiciales, 151409.

102 ADP, C/273-n ${ }^{\circ} 16$, fols. 13-18.

103 APNP, notario Juan Echeverz, Elizondo, leg. 93, 27 noviembre de 1696. 
Además añadió 150 ducados más que se destinaban a la memoria de su esposo por ser cabo de escuadra de la compañía del capitán Alonso Galgaya. ${ }^{104}$

En resumen, las capellanías eran «una masa de bienes afectos a un fin religioso, tanto si el fin consiste solamente en una carga real que grava bienes profanos, como si los bienes con su carga están espiritualizados. Para recibir su nombre necesita alguna carga de misas. No habiéndola recibe el nombre de fundación piadosa». ${ }^{105}$ Hay una nueva actitud ante la muerte, pues se encargaba orar por la propia alma y también la de cada uno de familia, pasada y por llegar. El honor que otorgaban las capellanías no era sino la regalía de presentar un clérigo elegido por el fundador, o por su patrono en el futuro, para que sirviera en dicha institución dentro de la parroquia. Quizá fuera éste el privilegio más representativo de todos aquéllos que representaban a nivel material la fundación de una capellanía.

\section{OBRAS PÍAS Y FUNDACIONES Y MANDAS PIADOSAS.}

Durante el Antiguo Régimen, el noble, para ser considerado tal, debía ser modelo de opulencia, de hospitalidad y de generosidad. Esto implicaba la fundación de diferentes obras pías y el mantenimiento de las ya creadas. Hay que analizar el hecho de la muerte dentro del momento cultural y social. La cultura de la muerte ayudaba a mantener el control social creando una nueva memoria piadosa del linaje. Tal aspecto cobraba especial importancia a través de la fundación de diferentes obras pías y de los patronazgos religiosos. La Iglesia del Antiguo Régimen ponía al alcance de los testadores la vida eterna a cambio de la inversión de parte de sus caudales en el socorro de los más desfavorecidos y los legados píos a fundaciones eclesiásticas.

Los actos caritativos estuvieron presentes en las biografías de los nobles navarros tanto en vida como las mandas pías de sus testamentos. Los donativos podían realizarse en metálico o haciendo entrega a los destinatarios de una serie de bienes de elevado precio. Normalmente este tipo de donaciones nobiliares tenían un fin concreto. Existieron multitud de legados hechos en apoyo de ermitas, templos y centros de devoción local o de gran importancia en la religiosidad del momento como los de San Miguel Excelsis, Roncesvalles, Ujué, Montserrat, El Pilar o Aránzazu.

En esta corriente devocional, el palaciano de Elio entregó en 15734 robos de trigo a Nuestra Señora de Reniega y los de Esparza y Artieda que ofrecieron otros 4 a Nuestra Señora de Musquilda y una carga de trigo a Santa María de

\footnotetext{
${ }^{104}$ APNP, Notario Miguel de Burutain, Pamplona, leg. 21-III, doc 3, 26 de noviembre de 1605, caja $18885 / 1$.

${ }^{105}$ Miguélez, L. 1953. «Capellanías y fundaciones piadosas», Revista Eclesia: 24.
} 
Arburúa en 1519.106 En 1690 doña Isabel de Subiza, palaciana de Zariquiegui y Esparza de Galar, donó, «para que sirva de perpetua memoria», una alfombra y una bandeja de plata a la iglesia donde se ubicaba su palacio para ser utilizados en los días de fiesta grande. ${ }^{107}$

Rocío García Bourrellier presenta el ejemplo del conde de Lerín. Don Luis de Beaumont legó en 1622 a la iglesia de Nuestra Señora de Legarda 6.000 maravedíes para que se concluyera la fabricación de su retablo. ${ }^{108}$ El conde de Lerín entregó dos vestidos de seda morada de oro para cubrir a la Virgen de una ermita del término de su jurisdicción. En 1684 la señora de Ezcurra, doña María de Acedo, donó dos arañas de plata para iluminar la ermita bajo la advocación de la Virgen del Villar. Fue una muestra más de su generosidad con las iglesias del lugar de Corella a las que hizo diferentes donaciones. ${ }^{109}$

Otro soporte económico del culto divino fue la entrega de dinero para la construcción o la reparación de edificios y obras de arte o la celebración de misas, al margen de las capellanías. Doña Juliana Ángela de Velasco, tía de la marquesa de Falces, fundaba a finales del siglo XVI una capilla en el monasterio de La Blanca de Marcilla. ${ }^{110}$ En este recinto sagrado solían enterrase los marqueses.

El marqués de Cortes destinó en vida 600 ducados para el oficio de diferentes misas y mantener encendida la lámpara de la iglesia de San Francisco de Olite.111

En 1612 en Galdeano, el abad y los primicieros de la parroquial de San Pedro, muchos de ellos nobles, pidieron licencia para la ejecución de excavaciones en el pavimento de la iglesia con el objeto de realizar un nuevo retablo dedicado al santo y que se pudiera poner un sagrario bien expuesto a la feligresía. ${ }^{112} \mathrm{El}$ retablo conservado hoy sigue una traza de banco, dos cuerpos de tres calles y dos entrecalles articuladas por columnas jónicas en el caso primero y compuestas en el segundo. Completa su aspecto arquitectónico un doble friso decorado con motivos vegetales en el inferior y con óvalos de santas mártires y virtudes en el superior. ${ }^{113}$

La aparición de representaciones nobiliares en el arte sacro se vincula igualmente con el concepto de 'donantes', es decir, con personajes contemporáneos a la fábrica de la obra, que se inmiscuían en un contexto sagrado. Esta fórmula

\footnotetext{
106 AGN, TT. RR., Procesos judiciales, 3867, fol. 30v y 1497, fol. 138.

107 APNP, notario Juan Arlegui, Pamplona, leg. 261, doc. 122bis.

${ }^{108}$ García Bourrellier, C. R. 1998 : 540-541.

109 Arrese, J. L. 1977: 18.

110 APNP, notario: Pedro Jiménez, Olite, c. 8.

111 AGN, Archivo Secreto del Consejo Real, Gobierno y Administración, L. 127.

112 APNP, caja 949/, notario Pedro Salinas, Salinas de Oro, leg. 72, doc. 2.

113 García Gainza, Ma . C. (dir.) 1982. Catálogo monumental de Navarra. Merindad de Estella: vol. II* 92-93 Pamplona: Príncipe de Viana.
} 
de mecenazgo personal de los artistas pervivió hasta el final del Antiguo Régimen. Aunque en principio constituyó básicamente un acto devocional, tras ella existía un ingrediente importante de ostentación piadosa y honorífica. Tengamos en cuenta que el retrato era un signo de reafirmación de la personalidad desde el Renacimiento. Por ello, en las imágenes situadas en espacios religiosos solían adoptar en ocasiones la iconografía del donante. ${ }^{114}$

Se puede identificar el retrato de Luis Cervantes y Enríquez de Navarra con su escudo junto a varios santos arrodillados a los pies de la Asunción, en la iglesia de la Victoria de Cascante, pintado al óleo sobre tabla por Rolan Mois. ${ }^{115}$

\section{Figura 1}

\section{Traza del retablo de la iglesia parroquial de Galdeano. ${ }^{116}$}

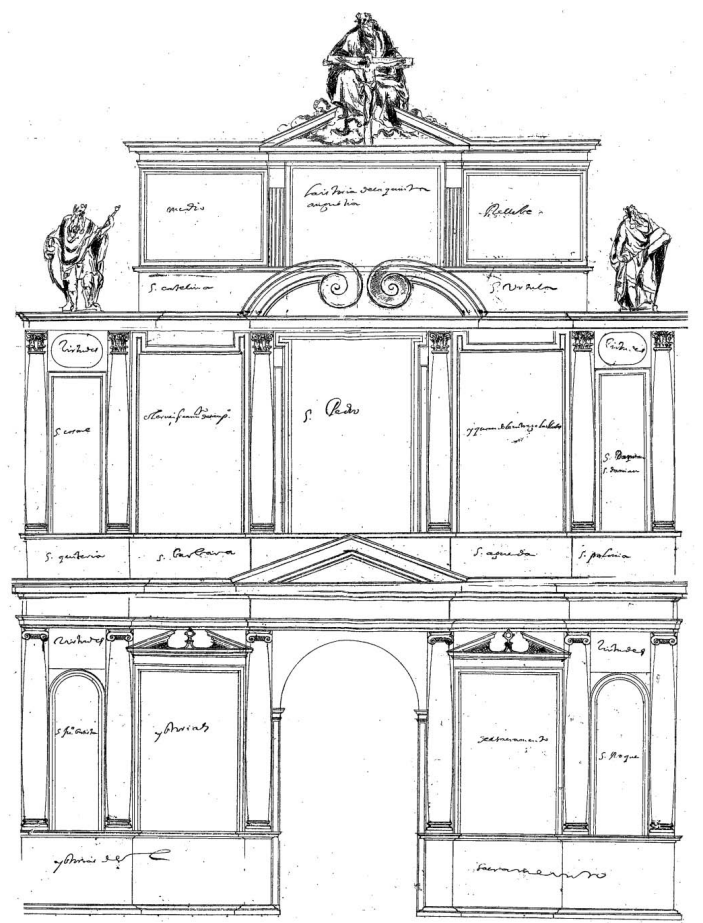

${ }^{114}$ Raquejo, M. A. 1981. «El donante en la pintura española del siglo XVI. Su ubicación en el espacio». Goya 164-165: 76-87.

115 Fernández Gracia, R. et alii. 2005. El arte del Renacimiento en Navarra: 297 Pamplona: Gobierno de Navarra.

${ }^{116}$ Fuente: APNP, notario Pedro Salinas, Salinas de Oro, caja 949/2, leg. 72, doc. 2 
En el monumento funerario de Carlos Mencos y su esposa María de Turrillas en el convento de Concepcionistas de Tafalla del cuál eran fundadores, en el ático del retablo mayor de la parroquia de Santa María Magdalena de Ablitas se halla un lienzo del Ecce-Homo sobre la esfera terrestre. En la pintura aparecen representados los señores de Ablitas y, sobre el pecho del conde, su escudo de armas así como junto a ellos sus alrmas y símbolos pasionarios y la Virgen del Pilar. ${ }^{117}$ La obra fue realizada por Juan de Gurrea por 730 ducados con la condición de seguir la traza de Estaragán según lo ya dispuesto por el vicario general. La ejecución de la obra concluyó en 1646 aunque su asentamiento definitivo se vio retrasado debido a diferentes pleitos entre el conde don Gaspar Enríquez de Lacarra y los vecinos sobre la colocación de los emblemas del primero en el retablo. ${ }^{118}$ Tras concluir el pago de Gurrea, sólo quedaba dorar la estructura arquitectónica del retablo y decorar sus compartimentos con pinturas en lienzos encomendadas al tudelano José de Fuentes. ${ }^{119}$

La nobleza navarra enseguida se sintió estrechamente vinculada a las nuevas devociones surgidas desde el siglo XVI. Prestaron su apoyo económico a jesuitas, franciscanos, benedictinos o clarisas. Citamos las grandes aportaciones económicas y diplomáticas de don Juan de Piñeiro, señor de Eriete, en la segunda mitad del siglo XVI para fundar los colegios jesuíticos de Pamplona en Navarra y Trápani en Sicilia. ${ }^{120}$ Tiempo más tarde la marquesa de Falces en 1646 encargó a los padres de la Compañía de Jesús del colegio tudelano que recorrieran cada año su territorio predicando. Pero su filiación con la Compañía no concluyó allí ya que en su testamento dispuso ser enterrada bien en el colegio de Pamplona o en el de Tudela que poseía esta orden. Para ello nombró como testamentarios a los rectores de ambos centros y destinó 3.000 ducados para el colegio en el que fuera sepultada. La hermana del conde de Javier testó nombrando como heredero universal al colegio de los jesuitas de Tarazona. ${ }^{121}$

En esa misma localidad aragonesa los vizcondes de Castejón mantuvieron una buena relación con el convento del Carmelo donde profesaba su hija. Tal vinculación se consolidó cuando decidieron que se les enterrara en el convento

117 García Gainza, Mª C. (dir.) 1980. Catálogo monumental de Navarra. Merindad de Tudela: vol. I* 3-4 Pamplona: Príncipe de Viana.

118 ADP, C/420-n ${ }^{\circ} 2$.

119 Fernández Gracia, R. 2002. El retablo barroco en Navarra: 182-183 Pamplona: Gobierno de Navarra.

${ }^{120}$ ADP, C/545-n ${ }^{\circ} 15$, fol. 305. De igual manera fundaría este noble navarro un convento de capuchinos en el lugar de Eriete testando entre 3.000 y 4.000 ducados de su hacienda para tal misión. Sin embargo, el referido convento nunca ha figurado entre los de la orden capuchina por lo que quizá nunca llegó a fundarse. Tampoco figurará ningún convento capuchino en Lesaca donde también otra palaciana, doña Catalina de Zabaleta, decidió destinar varios de sus bienes para su fundación en 1616.

${ }^{121}$ García Bourrellier, C. R. 1998 : 543. 
carmelita de Tudela. Era una sepultura temporal en espera del permiso para ser depositados sus cuerpos en el altar mayor de la catedral. ${ }^{122}$

En 1666, comenzaron en Tafalla las obras de construcción de un convento de capuchinos que se vieron concluido hacia $1696 .{ }^{123}$ Que esta orden se asentara en la ciudad se debió al empeño de doña Ana Jerónima de Ollacarizqueta y Sarría. Era señora de los palacios de Berbinzana, Ollacarizqueta y Mutilva. En su testamento de 1661 decidió destinar parte de sus bienes a su construcción, «movida del singular amor y devoción que tengo y siempre he tenido a mi Seraphico Padre San Francisco y a dichos Religiosos Capuchinos».124 Sólo exigía quedar como única dueña y fundadora y, si los padres capuchinos decidían que tal título fuera de otra persona la palaciana desviaría sus bienes al convento de San Agustín en Pamplona. Para evitarlo prohibió a los frailes aceptar donativos de otras personas, «quedando como ha de quedar in perpetuum por única dueña $\mathrm{y}$ fundadora».

Dispuso que, concluidas las obras, en el frontispicio se colocaran sus armas y las de su esposo «con un letrero que diga en esta forma: fundó este Convento doña Jerónima de Ollacarizqueta y Sarría Viuda de don Joan de Asiáin y Medrano a mayor honra y gloria de Dios». Y esto, según ella, no debía hacerse como muestra de vanidad sino para que existiera una perpetua memoria en los religiosos que allí habitaran de encomendar su alma a Dios. ${ }^{125} \mathrm{Su}$ piedad fue mayor que sus caudales y la obra le causó grandes dificultades y como estaba prohibida cualquier otra limosna, hasta los padres capuchinos tuvieron que trabajar en su construcción. ${ }^{26}$.

A lo largo del Barroco hubo otros ejemplos de fundaciones de conventos por miembros de la nobleza navarra. Además de los casos citados, a la iniciativa de don Martín Cruzat se debe el de los carmelitas descalzos de Pamplona, o el de los capuchinos en Elizondo en 1726 tras la fundación previa de un hospicio en la casa-palacio Arrechea, cedida a la orden por el noble baztanés don Juan Antonio Eslava y Berrio. 127

122 AGS, Contadurías de Mercedes, leg. 1.181, n. 10.

${ }^{123}$ Azanza, J. J. 1998b, Arquitectura religiosa del barroco en Navarra: 151 y 316 Pamplona: Gobierno de Navarra.

${ }^{124}$ AGN-Archivo del Palacio de Sarasa [APS], Copias, leg. 1, carp. 24.

${ }^{125}$ ADP, C/621-n 18 y C/945-n ${ }^{\circ} 2$, fol. 38. y 93v-107.

126 Azanza, J. J. 1998a. «La 'iglesia en la ciudad': arte, economía y espiritualidad en Navarra a la luz de las fundaciones conventuales barrocas». Príncipe de Viana 215: 598.

${ }^{127} \mathrm{Sin}$ embargo, esta última fundación no llegaría a buen puerto ya que el monarca, tras consultar a su consejo acerca de la dureza del lugar del citado futuro convento, ordenó al provincial de los capuchinos en Navarra que desistiese de tal empeño y desalojara el hospicio. $\mathrm{Y}$ así tuvieron que hacerlo en mayo de 1763. Añorbe, C. 1951. La antigua Provincia capuchina de Navarra y Cantabria (1578-1900): 331 Pamplona: Ediciones Verdad y Caridad. 
En este auge de fundaciones de conventos de la Edad Moderna destacó el interés de las elites por convertirse en patronos y protectores de una institución eclesiástica. Esto se debió en gran medida al deseo de emular a los propios monarcas. Esta 'fiebre devocional', como la definió Sánchez Lora, avanzada ya la Modernidad, se convirtió en un anhelo de todos los grupos sociales con poder económico o comunitario. ${ }^{128}$

En 1626 Fernández Navarrete señalaba el daño que cada día era más corriente apreciar al ver «muchos conventos comenzados a fabricar sin suficiente caudal de los patronos». ${ }^{129}$ Impulsaba estas construcciones una profunda religiosidad, pero también el pretendido prestigio social. González Dávila en su Historia de Felipe III afirmaba que «los señores y caballeros han introducido por vanidad, y por calificar sus lugares, y por emulación de sus semejantes, el tener un monasterio o más, y así lo procuran, alegando por excelencia de sus Estados el tener tantos monasterios, y fundándolos de descalzos por más baratos».130

A pesar de esta segunda motivación, las nuevas fundaciones posibilitaron el surgimiento de comunidades religiosas y el sostenimiento de lugares de culto por toda la geografía hispana. Esa revitalización de los espacios sacros se dejó notar sobre todo en las ciudades y los núcleos de población importantes. Se trataba, por tanto, de una nueva ubicación totalmente opuesta a la de los monasterios medievales, asentados en lugares aislados y en zonas rurales.

Dámaso Frías en sus Diálogos de 1579 ya apuntaba que «nunca fundan sus casas sino es en pueblos grandes y bien mantenidos [...] estos santos religiosos de nuestros tiempos no son amigos de hacer milagros en los desiertos de Egipto, ni en las Asturias de Oviedo, sino en el corazón de Madrid, a vista de su Majestad, en un Valladolid, Toledo, Sevilla, Granada, que jurare yo que hay más monasterios en sólo Valladolid, que en todas las Montañas, ni en toda Vizcaya. Pero bien está, que donde la mies es mucha es bien que los jornaleros sean muchos». ${ }^{131}$

El recogimiento de los religiosos en los núcleos de población respondía a las directrices de Trento que buscaban mayor seguridad para las congregaciones femeninas y mayor variedad espectro económicao y espiritual para las masculinas. Se trasladó el convento extramuros de benedictinas al interior del casco urbano de Lumbier en 1571-1572. ${ }^{132}$

\footnotetext{
${ }^{128}$ Sánchez Lora, J. L. 1988. Mujeres, conventos y formas de religiosidad barroca: 102 Madrid: Fundación Universitaria Española.

${ }^{129}$ Fernández Navarrete, P. 1853. Conservación de monarquías y discursos políticos sobre la gran consulta que el Consejo hizo al Señor Rey don Felipe III: t. XXV 538 Madrid.

${ }^{130}$ Citado por Domínguez Ortiz, A. 1970. La sociedad española en el siglo XVII. t. II: El estamento eclesiástico: 71 Madrid: Universidad de Granada.

${ }^{131}$ Citado por Cámara, A. 1990. Arquitectura y sociedad en el Siglo de Oro: 103 Madrid: El Arquero.

132 Goñi, J. 1947. Los navarros en el Concilio de Trento y la reforma tridentina de la diócesis de Pamplona: 274 Pamplona: Imprenta Diocesana.
} 
En 1592 Cock acompañando a Felipe II, a su llegada a Tudela quedó asombrado por el elevado número de edificios conventuales que descubrió en la ciudad. ${ }^{133}$ El desmoche de sus murallas y la prosperidad económica habían permitido que las órdenes religiosas se establecieran unas pegadas a otras en un radio de poco más de medio kilómetro en torno al barrio de la Morería. Existían catorce conventos a pesar de ser una ciudad de tercer rango poblacional en el conjunto peninsular.

Algunos nobles fundadores se habían enriquecido con la administración de sus tierras y negocios. Otros lo habían hecho desempeñando cargos políticos en el Reino, en la Corte o en Indias. La mayor parte descendían de casas palaciegas de la Navarra húmeda del noroeste y en consecuencia, a finales del siglo XVII, en estos valles de la Merindad de las Montañas se localizaron importantes donaciones. ${ }^{134}$ En otras zonas de la merindad se reinvirtieron legados que pararon en Pamplona, Puente la Reina o Valdizarbe. En los otros territorios se beneficiaron de estos legados madrileños e indianos o localidades como Tudela, Corella, Viana, Olite, Tafalla, Arróniz o Sesma. Destacaron así figuras como don Juan de Ciriza y su esposa doña Catalina de Alvarado, que tras ser él nombrado secretario de Felipe III en 1601 comenzó una prospera carrera en la Corte madrileña. Ambos tuvieron dinero suficiente para sufragar tiempo después los gastos de la construcción del convento de las agustinas recoletas de Pamplona donde se hallan dos retratos suyos. ${ }^{135}$

En el siglo XVIII volveremos a encontrar nuevos ejemplos del mecenazgo nobiliar, como la financiación del convento de clarisas de Arizcun por don Juan Bautista Iturralde, marqués de Murillo el Cuende y señor de los palacios de Olóriz, Sansomáin y Benegorri aunque natural de la casa baztanesa Iturraldea. En este convento tuvieron preferencia para profesar las jóvenes de Arizcun y de todo el Valle de Baztán. 136

Las obras pías no sólo supusieron durante la Modernidad la fundación de nuevos monasterios. En la práctica cristiana el necesitado tiene un valor religioso, pues se identifica con Jesucristo. La limosna se hace según el texto del evangelio. ${ }^{137}$ La patrística, desde Eusebio de Cesarea a Ambrosio de Milán, ha-

${ }^{133}$ Cock, E. 1927. «Felipe II y la jornada de Navarra en 1592». Boletín de la Comisión de Monumentos de Navarra: 597.

${ }^{134}$ Arizcun, A. 1988. Economía y sociedad en un Valle pirenaico del Antiguo Régimen. Baztán 1600-1841: 372 Pamplona: Gobierno de Navarra.

${ }^{135}$ Segovia, M. C. 1980 . «El convento de Agustinas Recoletas de Pamplona», B.S.A.A.V.: 255-257.

136 Azanza, J. J. 1998b: 142.

137 «...cuando hagas limosna, no lo vayas trompeteando por delante como hacen los hipócritas en las sinagogas y por las calles, con el fin de ser honrados por los hombres; en verdad os digo que ya reciben su paga. Tú, en cambio, cuando hagas limosna, que no sepa tu mano izquierda lo que hace tu derecha; así tu limosna quedará en secreto; y tu Padre, que ve en lo secreto, te recompensará» (Mateo 6 2-4)

Hispania Sacra, LXIV

130, julio-diciembre 2012, 583-622, ISSN: 0018-215X, doi: 10.3989/hs.2012.018 
bía desarrollado la idea de la pobreza como valor cristiano. Por eso los pobres, marginados y necesitados debían ser atendidos por caridad. En el Renacimiento se opone la figura del necesitado a la del rico. A finales del Quinientos se modifica la mentalidad favorable a la pobreza. ${ }^{138}$ Los pobres comenzaron a ser vistos como un signo del rechazo divino. ${ }^{139}$ No obstante, la necesidad de la limosna volvió a resurgir en los autores católicos como Falcó, De Angelis, Bartoli, Sperelli o Berlarmino durante la Era Confesional. El rico era considerado un administrador de sus bienes y según estos autores estaba obligado a dar lo superfluo a los pobres como 'pars Christi'.

Se observa la influencia de Vives o de Erasmo en la real cédula que emitió en 1540 Carlos V: «que los pobres verdaderos fuesen alimentados y que ninguno anduviese a pedir por puertas y calle». Fray Juan de Robles, también contrario a quienes daban limosna por las calles, se mostrará más partidario de esta medida y de ayudar al pobre en su casa. Otros escritores como Soto o Medina se mostraron, en cambio, opuestos a esta orden defendiendo como sagrada la libertad del pobre. ${ }^{140}$

En la segunda mitad del siglo XVII, como ejemplo de participación caritativa en Navarra podemos señalar el censo legado por el hidalgo Diego Jacinto de Arguedas y su esposa, Agustina del Palo, para la mesa de pobres de la iglesia colegial tudelana. En esta actividad benéfica participaba todo el estamento nobiliario de la capital ribera. ${ }^{141}$

A principios del Setecientos se buscaba ocultar al pobre y se le internaba en fundaciones caritativas. ${ }^{142}$ La pobreza era considerada entonces más que un asunto religioso un problema de Estado (Pérez Estévez, 1976). Durante el último tercio del siglo XVIII esta preocupación gubernamental derivó en la Península en una vasta operación profiláctica represiva contra mendigos, vagos y malentretenidos. En el reinado de Carlos III se intentó recoger a todos los vagabundos en hospicios para que convirtieran en personas útiles para la comunidad.

En el Antiguo Régimen el hospital no era sólo lugar de curación sino también de asilo. En palabras de Rubio Vela, «enfermedad y pobreza eran dos conceptos inseparables en la organización hospitalaria de la época». ${ }^{143}$ A principios

${ }^{138}$ Saborit, P. 1991. Morir en el Alto Palancia (La religiosidad popular a través de los testamentos. Siglos XVI-XVIII): 278 Segorbe: Ayuntamiento de Segorbe.

${ }_{139}$ Ricci, G. 1983. «Naissance du pauvre honteux. Entre l'historie des ideés et l'histoire social». Annales 38: 158-173.

140 Maza, E. 1987. Pobreza y asistencia social en España: 87 y ss. Valladolid: Universidad de Valladolid.

141 AGN, TT. RR., Procesos judiciales, 122969.

${ }^{142}$ Fiorani L. 1979. «Religione e povertá: Il dibattito sul pauperismo a Roma tra cinquecento e seicento». Ricerche per la storia religiosa di Roma 3: 44-132.

${ }^{143}$ Rubio, A. 1984. Pobreza, enfermedad y asistencia hospitalaria en la Valencia del siglo XIV: 15 Valencia: Institución Alfonso el Magnánimo. 
del siglo XVI el doctor Ramiro de Goñi, arcediano de la Tabla de la catedral pamplonesa y hermano del palaciano de Goñi, buscó el apoyo económico de muchos nobles navarros. El destino de sus limosnas debía ser el Hospital General de Nuestra Señora de la Misericordia fundado por él para dar amparo a los menesterosos. ${ }^{144}$ En 1558 recibió la ayuda de 6 ducados anuales de un censal de 75 proveniente de la generosidad del palacio de Artázcoz. Ocho años más tarde le donaría otros 6 ducados el señor de Ezcurra y en 1568 la palaciana de Echálaz legó una carga de trigo. Y así sucesivamente hasta los 6 robos de trigo que ofrecería el palaciano de Beunzalarrea en $1654 .{ }^{145}$ La Orden de San Juan de Jerusalén también recibió donaciones de nobles navarros para sostener su labor hospitalaria en el Reino. En 1630 el palaciano de Olleta de Lónguida donaba 100 reales a la «Casa Santa de Jerusalén».146

Las últimas disposiciones de fray Miguel de Eza, caballero de la Orden de Alcántara, se firmaron en la ciudad de Tudela en 1549. En ellas señalaba que «entre las miserias humanas una de las más principales es la falta de la salud corporal y como las pobres gentes por falta de hacienda dejan de curar de muchas enfermedades corporales y de ello se siguen muchos y muy grandes trabajos en las personas que las padecen y grandes daños en las repúblicas», decidió donar todos sus bienes a la institución del Hospital General de Santa María. ${ }^{147}$

La fundación se ubicaba en 1 de Tudela. En sus voluntades el caballero ordenaba que, como patronos, deberían juntarse «el día que el atte de esta ciudad acostumbra a tomar la vara y elijan en cada año y nombren el atte justicia y jurados un ciudadano y el deán y cabildo una persona de los del dicho cabildo y encargo que las tales personas sean honradas y diligentes y celosas del servicio de Dios porque desde ahora para entonces a las tales personas cometo la administración y gobierno de dicho hospital y les doy el mismo poder que tengo dado a sus principales». ${ }^{148}$ Ordenaba asimismo que se edificara una capilla en el centro sanitario «de buen tamaño y proporción tal cual sea bastante para recoger buena parte del pueblo cuando se quisieren congregar los divinos oficios». En ella debía colocarse un retablo mediano con una imagen de la Piedad con ornamento de terciopelo azul así como las armas personales del noble visibles en el recinto y en los útiles de culto, todos de plata, dejando para tal sección de la obra general 3.000 ducados de oro viejo. Igualmente ordenaba que se le

\footnotetext{
${ }^{144}$ Martinena, J. J. 1997. Guía del Archivo General de Navarra: 243-245 Pamplona: Gobierno de Navarra.

145 AGN, TT. RR., Procesos judiciales, 15998, fol. 7; 69038, fol. 3, 31300, fol. s/n y ADP, C/418$\mathrm{n}^{\mathrm{o}} 2$, fols. 29-36.

146 ADP, C/354-n ${ }^{\circ} 18$, fols. 2-4.

147 AGN-AM-P. Tudela, n. 36b, fol. 2r.

148 Ídem.
} 
hiciera en dicho lugar «un enterramiento de alabastro que no sea muy costoso» junto con un paño de terciopelo negro con el hábito de Alcántara para los días de fiesta y otro sólo de terciopelo negro para enterrar a los enfermos difuntos del hospital.

La institución tampoco debía olvidar su función de asilo para necesitados, por lo que Miguel de Eza mandó que se construyera una casa de cuatro cuartos para «que en ella se recojan los pobres de Jesucristo», lugar que también debía contar con su escudo personal en la fachada. Junto a ella habría que buscar un lugar de enterramiento para los muertos en el hospital. Ordenaba que se compraran todos los corrales y fincas necesarias para poder edificar su obra en sus solares a la par que toda la ropa y útiles necesarios para su mantenimiento y funcionamiento.

Al capellán y al hospitalero del recinto se les debía asignar un sueldo y al primero de ellos se le encomendaba una misa diaria así como confesar y administrar los sacramentos. Al hospitalero le encargó realizar los inventarios y gobernar la casa.

El plazo de ejecución de sus últimas voluntades sería seis años con un presupuesto de 10.000 ducados todo ello por «el bien y utilidad de la ciudad». ${ }^{149}$

Siglo y medio más tarde, en 1696, en Elizondo dictaba testamento el capitán don Miguel de Vergara, caballero santiaguista y dueño del palacio de Jarola. Tenía una hija monja profesa en el convento de las hermanas dominicas de Sevilla. Al carecer de heredero optó por fundar con sus bienes un mayorazgo electivo y designar como sucesor a su sobrino don Pedro de Borda y Vergara. Para «agradar y servir a Dios», el palaciano solicitó la demolición del antiguo hospital de Elizondo para construir uno nuevo. Él costearía los gastos «de manera que sea más capaz para hospedar a los pobres y peregrinos que transitaren y llegaren al dicho lugar». 150

Este mismo año de 1696 volvería a apreciarse la profunda piedad del señor de Eriete, don Juan de Piñeiro. Dejó entre sus últimas voluntades redactado su deseo de fundar un «convento senil» en su lugar de origen con capacidad para albergar a doce ancianos «en honor y reverencia a los doce apóstoles de Cristo». No era tanto un hospital de enfermos como una residencia para ancianos sanos aunque desvalidos. Don Juan fijó las normas al detalle en su testamento, disponiendo que vistieran con un sayal grueso semejante al de los capuchinos. También ordenó que se les dispusiera de ocho camas nuevas con buen jergón de lana y cuatro sábanas. Junto a los ancianos debería haber un sacerdote para las necesidades espirituales, para los sacramentos y para celebrar una misa

\footnotetext{
149 Ibídem, fols. 3r-5r.

${ }^{150}$ APNP, notario Juan Echeverz, Elizondo, leg. 93, 27 de noviembre de 1696.
} 
diaria de réquiem por el fundador. A la hora de comer, tras agradecer los alimentos a Dios y rezar un padrenuestro junto a un avemaría por él y sus difuntos, se les ofrecería «su pan y su vino y su olla de carne» y los días de pescado «su olla con legumbres y algún potaje» y si alguno tuviera «necesidad de huevos se los darán». Para hacer frente a los gastos y la manutención del capellán y los abuelos, Piñeiro dispuso que su heredero comprara 300 ducados de renta perpetua. ${ }^{151}$

CONCLUSIONES: NUEVO CONCEPTO DE ESPIRITUALIDAD NOBILIAR MODERNA.

En la sociedad de los siglos XVI-XVIII había un estamento privilegiado, pero no unitario. Traspasada la difusa frontera entre el Medioevo y la Modernidad, el marco socio-cultural del Reino no quedó plenamente configurado. El siglo XVI había heredado de la Edad Media un régimen estamental feudal. En el vértice superior de esta estructura social seguían los mismos grupos dominantes del pasado. Si bien eran bastante evidentes las divisiones internas en la nobleza, sus miembros eran las personas más eminentes de la comunidad, Formaban la elite social y cultural.

La jerarquización interna del grupo la fijaban las diferencias de poder, de influencia, de prestigio o de antigüedad de linaje. Con el tiempo estas preeminencias se desnaturalizaron, pero sin que quebrara el orden jerárquico comunitario. Estas categorías internas de la sociedad navarra del Antiguo Régimen establecían las reglas de comportamiento particulares de los caballeros y damas con respecto a sus iguales, inferiores y superiores.

Este, en apariencia, coherente sistema de ordenación escalonada de la estructura social, pudo resistir los cambios propios de la Modernidad y los conflictos de tipo estamental gracias a la gestión de una serie de solidaridades que articularon la vida colectiva. Este espacio de poder, donde la honra y el honor marcaban las pautas de comportamiento según rígidas normas de protocolo y cortesía que atendían a condicionantes como el espacio, la persona y el momento. El honor afectaba durante el Antiguo Régimen a lo más hondo de la personalidad del noble. Por ello un agravio a la honra significaba una lesión en lo más interno e intransferible del individuo. En el siglo XVII la moral aportó directa o indirectamente, como hemos podido ver, un doble sentido a la honorabilidad nobiliaria, basado en la importancia de sustentar la honra del caballero.

Según el ideario social de la época, el noble era consciente de que su honradez era parte de su propia nobleza. Estos honores marcaban tácitamente su

\footnotetext{
${ }^{151} \mathrm{ADP}, \mathrm{C} / 545-\mathrm{n}^{\circ} 15$.
} 
imagen con respecto a los otros. La honra constituyó en definitiva una expresión laica de la coherencia y necesidad de un orden en el 'lugar común' del vecindario, el pueblo o la villa. Por ello, la palabra deshonra hacía referencia a un acto y no sólo a un sentimiento.

La distinción estamental se hacía patente en la medida en que las elites sociales hicieron valer sus privilegios y mantuvieron vivas sus preeminencias frente al resto de la comunidad. La creación de este 'mundo aparte' se manifestó de forma especial en su nueva manera de participación religiosa.

Si nos alejamos de los ámbitos más mundanos, en el análisis del comportamiento de este grupo hemos observado la importancia que dieron los nobles navarros a la dimensión espiritual de sus vidas. Durante el Antiguo Régimen la religión impregnaba todos los actos de mayor trascendencia comunitaria. La presencia de la nobleza en diferentes manifestaciones religiosas quedó patente a través de su participación en actos de culto, hermandades o el patronato artístico y espiritual. Como era normal, en la Modernidad europea los nobles vivieron una religiosidad activa en el día a día. De ello se deriva, en concreto, su inserción en organismos religiosos de carácter secular del mundo cofrade o del de las órdenes militares.

A través de esta militancia activa, la espiritualidad de la nobleza quedó particularizada en función de su situación social, siendo un elemento más de la diferenciación social del Antiguo Régimen. Las nuevas formas de espiritualidad gestadas en la Era Confesional llegaron a los hogares de la nobleza, haciendo emerger cierta individualidad y enfrentando en muchos casos a nuestros personajes con tradiciones anteriores.

El valor honorífico de la sepultura no desapareció, pero la muerte fue aceptada con un mayor realismo y naturalidad. A este respecto, se ha podido comprobar que nada era improvisado por la nobleza navarra. Así, se puso un especial cuidado en los detalles de cada ritual funerario y en las disposiciones de última voluntad. En definitiva, puede afirmarse que cobraron especial importancia los testamentos, las mandas pías y los rituales funerarios, existiendo una constante lucha entre la nueva sobriedad post-tridentina y el deseo de magnificencia. En cualquier caso, para finalizar, queremos dejar claro que no ha sido nuestro fin llegar a una conclusión cerrada sobre la religiosidad nobiliar en la Navarra del Antiguo Régimen sino potenciar un nuevo marco de estudio, un campo de trabajo que esperamos ayude a ampliar muchos de los datos e interpretaciones. Todo ello permitirá enriquecer el discurso del pensamiento histórico acerca de la sociedad de la Modernidad, y abordarlo revisando los conceptos de espiritualidad, colectividad y honor. 
BIBLIOGRAFÍA CITADA.

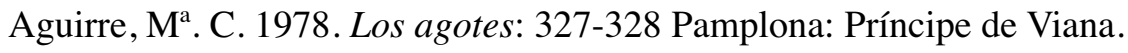

Añorbe, C. 1951. La antigua Provincia capuchina de Navarra y Cantabria (1578-1900): 331 Pamplona: Ediciones Verdad y Caridad.

Ariès, P. 1983. El hombre ante la muerte: 35 Madrid: Taurus.

Arizcun, A. 1988. Economía y sociedad en un Valle pirenaico del Antiguo Régimen. Baztán 1600-1841: 372 Pamplona: Gobierno de Navarra.

Arrese, J. L. 1977. Colección de biografías locales: 138 y 424 San Sebastián: Industria Gráfica Valverde.

Arroyo, J. L. 2007. «Capellanías de la vicaría de Viana». Cuadernos del Marqués de San Adrián 5: 39-90.

Azanza, J. J. 1998a. «La 'iglesia en la ciudad': arte, economía y espiritualidad en Navarra a la luz de las fundaciones conventuales barrocas». Príncipe de Viana 215: 598.

Azanza, J. J. 1998b, Arquitectura religiosa del barroco en Navarra: 151 y 316 Pamplona: Gobierno de Navarra.

Azanza, J. J. y Molins, J. L. 2005. Ceremonial funerario, arte efímero y emblemática. Exequias reales del regimiento pamplonés en la Edad Moderna. Pamplona: Ayuntamiento de Pamplona.

Barreiro, B. 1983. «La nobleza asturiana ante la vida y la muerte». Actas del II Coloquio de Metodología Histórica Aplicada. La documentación notarial y la Historia II: 39 y ss.

Barrio Gozalo, M. 1982. Estudio socio-económico de la Iglesia de Segovia en el siglo XVIII. Segovia: Caja de Ahorros y Monte de Piedad de Segovia.

Barrio Gozalo, M. 1992. «Las condiciones materiales del clero parroquial del obispado de Segovia en el siglo XVIII (II): la realidad de los ingresos y los gastos». Investigaciones históricas: Época moderna y contemporánea 12: 119.

Bonet, A. 1990. Fiesta, poder y arquitectura. Aproximaciones al barroco español: 18-25 Madrid: Akal.

Bouza, J. L. 1990. Religiosidad contrarreformista y cultura simbólica del Barroco: 377-398 Madrid: CSIC.

Calvi, M. 2007. «La capellanía: una forma rinnovata di assistenza spirituale». Quaderni di diritto ecclesiale vol. 20, 3: 227-239.

Cámara, A. 1990. Arquitectura y sociedad en el Siglo de Oro: 103 Madrid: El Arquero. 
Campa, R. 2003. «Iglesia y religiosidad española según la condesa D’Aulnoy (segunda mitad del siglo XVII)», en M. B. Villar y P. Pezzi (eds.), Los extranjeros en la España moderna. Actas del I Coloquio Internacional: tomo II, 170. Málaga: [s.n.].

Casey, J. 2002. «Queriendo poner mi ánima en carrera de salvación: la muerte en Granada (siglos XVII y XVIII)» en G. Franco Rubio (coord.), De mentalidades y formas culturales en la Edad Moderna. Cuadernos de Historia Moderna, Anejo I 17-43: 17-43.

Castro, C. Calvo, M. y Granado, S. 2007. «Las capellanías en los siglos XVII-CVIII a través del estudio de su escritura de fundación». Anuario de Historia de la Educación XVI: 335-347.

Cock, E. 1927. «Felipe II y la jornada de Navarra en 1592». Boletín de la Comisión de Monumentos de Navarra: 597.

Díaz, J. 2003. «Prestigio social del estamento nobiliario: el patronazgo eclesiástico asturiano de los Vigil de Quiñones en el siglo XVII». Revista de Historia Moderna 21: 274.

Domínguez Ortiz, A. 1970. La sociedad española en el siglo XVII. t. II: El estamento eclesiástico: 71 Madrid: Universidad de Granada.

Domínguez Ortiz, A. 1979. Las clases privilegiadas en el Antiguo Régimen: 252 Madrid: Istmo.

Erasmo, D. 1998. El Enquiridion o manual del caballero cristiano: regla I, cap. VII, Valladolid: Secretariado de Publicaciones de la Universidad de Valladolid.

Erasmo, D. 2000. Preparación y aparejo para bien morir: 281 Madrid: Fundación Universitaria Española.

Escudeo, Fco. J. 2003. «Cofradías, capellanías y patronazgos (s. XV-XVI)», en $\mathrm{M}^{\mathrm{a}}$. Dolores Zaldívar (coord.), I Jornadas de Patrimonio Religioso de la Villa de Socuéllamos: 41-62.: Ayuntamiento de Socuéllamos.

Fernández Gracia, R. 1998. «El túmulo de Felipe II en la catedral de Pamplona». Actas del Congreso Internacional: Felipe II y las Artes: 453-464.

Fernández Gracia, R. 2002. El retablo barroco en Navarra: 182-183 Pamplona: Gobierno de Navarra.

Fernández Gracia, R. et alii. 2005. El arte del Renacimiento en Navarra: 297 Pamplona: Gobierno de Navarra.

Fernández Navarrete, P. 1853. Conservación de monarquías y discursos políticos sobre la gran consulta que el Consejo hizo al Señor Rey don Felipe III: t. XXV 538 Madrid. 
Fernández, I. 1666. Apostólica y penitente vida del V. P. Pedro Claver, de la Compañía de Iesus: 236 Zaragoza: Juan María Sola.

Fiorani L. 1979. «Religione e povertá: Il dibattito sul pauperismo a Roma tra cinquecento e seicento». Ricerche per la storia religiosa di Roma 3: 44-132.

García Bourrellier, C. R. 1998. Nobleza titulada y organización señorial en Navarra (siglo XVII): 549 y ss. Pamplona: Tesis doctoral inédita.

García Fernández, M. 1996. Los castellanos y la muerte. Religiosidad y comportamientos colectivos en el Antiguo Régimen: 22-24 Valladolid: Junta de Castilla Y León.

García Gainza, Ma . C. (dir.) 1980. Catálogo monumental de Navarra. Merindad de Tudela: vol. I* 3-4 Pamplona: Príncipe de Viana.

García Gainza, $\mathbf{M}^{\mathrm{a}}$. C. (dir.) 1982. Catálogo monumental de Navarra. Merindad de Estella: vol. II* 92-93 Pamplona: Príncipe de Viana.

Gittings, C. 1984. Death, burial and the individual in early modern England: 153-161 Londres: Helm.

Goñi, J. 1947. Los navarros en el Concilio de Trento y la reforma tridentina de la diócesis de Pamplona: 274 Pamplona: Imprenta Diocesana.

Idoate, F. 1959. El Señorío de Sarría: 234 Pamplona: Gráficas Iruña.

Jara, J. 1996. «Muerte, ceremonial y ritual funerario: procesos de cohesión intraestamental y de control social en la alta aristocracia del Antiguo Régimen (Corona de Castilla, siglos XV-XVIII)». Hispania 194: 861-864.

Levaggi, A. 1992. Las capellanías en Argentina. Estudio histórico-jurídico: 21 Buenos Aires: UBA.

Lorenzo, Fco. J. 1991. Muerte y ritual en la Edad Moderna. El caso de Zamora (1500-1800): 19, 33 y 80 Salamanca: Universidad de Salamanca.

Madariaga, J. 1998. Una noble señora, herio anderea: actitudes ante la muerte en el País Vasco: 168-174 Bilbao: UPV-EHU.

Male, E. 1986. L'art religieux du XIIIe siécle en France : 206-217 Paris : Colin.

Marín, J. 1682. Vida, virtudes, y misiones del venerable P. Jerónimo López misionero apostólico de la Compañía de Iesús de la provincia de Aragón: 135 y 141 Roma: Varesio.

Martinena, J. J. 1997. Guía del Archivo General de Navarra: 243-245 Pamplona: Gobierno de Navarra.

Martínez, F. 2002. «Del modelo medieval a la Contrarreforma: la clericalización de la muerte», en J. Aurell y J. Pavón (eds.), Ante la muerte. Actitudes, espacios y formas en la España Medieval: 215-255. Pamplona: EUNSA. 
Maza, E. 1987. Pobreza y asistencia social en España: 87 y ss. Valladolid: Universidad de Valladolid.

Mesquida, J. 2010. «La población de Manila y las capellanías de misas de los españoles: libro de registros, 1642-1672». Revista de Indias 249: 469-500.

Miguélez, L. 1953. «Capellanías y fundaciones piadosas», Revista Eclesia: 24.

Montero, C. 1998. «La capellanía: una de las prácticas religiosas para el más allá», en Ma . P. Martínez, G. Von Wobeser y J. G. Muñoz (coords), Cofradías, capellanías y obras pías en la América Colonial: 134. México: Universidad Nacional Autónoma de México.

Muñoz, J. G. 1998. «Las estrategias de una elite frente a la Tierra y el Cielo: capellanías en Colchagua en el siglo XVII», en $\mathrm{M}^{\mathrm{a}}$. P. Martínez, G. Von Wobeser y J. G. Muñoz (coords.), Cofradías, capellanías y obras pías en la América Colonial: 159. Universidad Nacional Autónoma de México.

Noáin, J. J. 2003. Nobleza media de Navarra en la Edad Moderna. Régimen señorial, familia, mentalidad, (siglos XVI-XVII): 354 Pamplona: Tesis inédita.

Novíssima Recopilación de las Leyes del Reino de Navarra... Año 1735, Pamplona, 1964 [NR], 3, 16, 2-5 y 8.

Peñafiel, A. 1987. Testamento y buena muerte. Un estudio de mentalidades en la Murcia del siglo XVIII: 38-41 Murcia: Academia Alfonso X El Sabio.

Pérez de Lara, A. 1733. Opera omnia: prólogo Lyon: Hermanos Deville.

Portús, J. 2004. «Infiernos pintados: iconografía infernal en la Edad Moderna hispánica», en M. Tausiet y J. S. Amelang (eds.), El Diablo en la Edad Moderna: 258. Madrid. Marcial Pons.

Portús, J. y Vega, J. 1998. La estampa religiosa en la España del Antiguo Régimen: 216 Madrid: Fundación Universitaria Española.

Pro Ruiz, J. 1988. «Tratamiento de las capellanías en los estudios de historia de la propiedad de la tierra en Castilla». I Congreso de Historia de Castilla-La Mancha. Conflictos sociales y evolución económica en la Edad Moderna 8: 327-330.

Pro Ruiz, J. 1989. «Las capellanías. Familia, iglesia y propiedad en el Antiguo Régimen». Hispania Sacra 84: 585-602.

Raquejo, M. A. 1981. «El donante en la pintura española del siglo XVI. Su ubicación en el espacio». Goya 164-165: 76-87.

Ricci, G. 1983. «Naissance du pauvre honteux. Entre l'historie des ideés et l'histoire social». Annales 38: 158-173.

Rodríguez Sánchez, A. 1994. «La muerte en España: del miedo a la resignación», en E. Serrano Martín (ed.), Muerte, religiosidad y cultura popular, siglos XIII-XVIII: 51-52. Zaragoza: Institución Fernando el Católico. 
Rodríguez-San Pedro Bezares, L. E. y Sánchez Lora, J. L. 2000. Los siglos XVI y XVII. Cultura y vida cotidiana: 161-162 Madrid: Síntesis.

Rubio, A. 1984. Pobreza, enfermedad y asistencia hospitalaria en la Valencia del siglo XIV: 15 Valencia: Institución Alfonso el Magnánimo.

Saborit, P. 1991. Morir en el Alto Palancia (La religiosidad popular a través de los testamentos. Siglos XVI-XVIII): 278 Segorbe: Ayuntamiento de Segorbe.

Sánchez Lora, J. L. 1988. Mujeres, conventos y formas de religiosidad barroca: 102 Madrid: Fundación Universitaria Española.

Sanmartín, R. 2006. El arte de morir. La puesta en escena de la muerte en un tratado del siglo XV: 13-26 Madrid: Iberoamericana.

Segovia, M. C. 1980. «El convento de Agustinas Recoletas de Pamplona», B.S.A.A.V.: 255-257.

Solchaga, J. 1959. El testamento ante párroco en Navarra. Zaragoza: Tipográfica La Académica.

Soria, E. 2002. «Las capellanías en la Castilla moderna: familia y ascenso social», en A. Irigoyen y A.L. Pérez (eds.), Familia, transmisión y perpetuación (siglos XVI-XIX): 137-139. Murcia: Universidad de Murcia.

Usunáriz, J. M ${ }^{\mathrm{a}}$.1991. «Un aspecto de la emigración navarra hacia el Nuevo Mundo durante el siglo XVIII: las remesas indianas». Segundo Congreso General de Historia de Navarra. 2. Comunicaciones, Príncipe de Viana, anejo 13: 383-392.

Varela, J. 1990. La muerte del rey. El ceremonial funerario de la monarquía española (1500-1885): 31 Madrid: Turner.

Venegas, A. 1583. Agonía del tránsito de la muerte: XXr Valladolid.

Videgain, F. 1992. La muerte en Navarra a través de los siglos: 226-230 Torres de Elorz: Castuera.

Wobeser, G. 1998. «La fundación de capellanías de misas, una costumbre arraigada entre las familias novohispanas: siglos XVI-XVIII». Jahrbuch für Geschichte Lateinamerikas 35: 25-44.

Zabalza, A. et alii. 1994. Navarra 1500-1850 (Trayectoria de una sociedad olvidada): 64 Pamplona: Ediciones y Libros. 